\title{
Re-evaluating the Neolithic: The Impact and the Consolidation of Farming Practices in the Cantabrian Region (Northern Spain)
}

\author{
Miriam Cubas ${ }^{1} \cdot$ Jesús Altuna $^{2}$ - Esteban Álvarez-Fernández 3 • \\ Angel Armendariz ${ }^{4}$ Miguel Ángel Fano ${ }^{5}$ Inés L. López-Dóriga ${ }^{4}$. \\ Koro Mariezkurrena ${ }^{2}$ Jesús Tapia ${ }^{6} \cdot$ Luis C. Teira $^{4}$. \\ Pablo Arias ${ }^{4}$
}

(c) The Author(s) 2016. This article is published with open access at Springerlink.com

\begin{abstract}
Research projects undertaken in the Cantabrian region since 1980 have produced new, high-quality information about the neolithisation process(es) in this area. It is now necessary to review this archaeological information and test the main hypotheses put forward to explain it. This paper presents an update on the archaeological evidence (sites, chronological dates, archaeozoological, archaeobotanical and technological information) for the early Neolithic in the Cantabrian region. It summarizes recent research on neolithisation in the region, and assesses the impact of this process during the early
\end{abstract}

Electronic supplementary material The online version of this article (doi:10.1007/s10963-016-9091-2) contains supplementary material, which is available to authorized users.

\author{
Miriam Cubas \\ miriam.cubas@york.ac.uk \\ Jesús Altuna \\ altuna@arkaios.com \\ Esteban Álvarez-Fernández \\ epanik@usal.es \\ Angel Armendariz \\ angel.armendariz@unican.es \\ Miguel Ángel Fano \\ miguel-angel.fano@unirioja.es \\ Inés L. López-Dóriga \\ i.lopezdoriga@wessexarch.co.uk \\ Koro Mariezkurrena \\ altuna@arkaios.com \\ Jesús Tapia \\ jtapia@aranzadi-zientziak.org \\ Luis C. Teira \\ luis.teira@unican.es \\ Pablo Arias \\ pablo.arias@unican.es
}


Neolithic, and its later consolidation. Although the available information is still incomplete, it is now possible to identify the focal point of the introduction of elements characteristic of the Neolithic way of life in the region. Current evidence suggests that it is in the eastern sector, where the earliest arrival of domesticates and new technologies such as pottery has been attested. The existence of continuities - such as sustained reliance on hunting and gathering and the coexistence of old and new funerary rites-suggests the persistence of native populations, which gradually participated in the neolithisation process after an 'availability phase'.

Keywords Cantabrian region - North of Spain - Neolithic - Mesolithic, chronology · Domesticates $\cdot$ Cereal $\cdot$ Pottery $\cdot$ Funerary record $\cdot$ Paleodiets

\section{Introduction}

Neolithisation processes of different kinds affected the whole of Europe and put an end to the hunter-gatherer way of life. However, these processes followed different chronological and strategic trajectories in different parts of the continent, so regional studies are needed to enable us to understand this crucial episode in human development. Two main neolithisation trends have been identified in southwestern Europe: the Linear Band Ker$\operatorname{amik}(L B K)$ culture in Central Europe and the Impressed Ware in the Mediterranean region. As a result of its geographical position, the Iberian peninsula experienced a different neolithisation process (or processes), with its own chronology and characteristics, involving changes in the material culture which are reflected archaeologically in a different way.

The earliest neolithisation evidence in the Iberian peninsula, dating to the first half of the sixth millennium cal BC and occurring on the Mediterranean coast, relates to Cardial (Martins et al. 2015) or Impressed pottery (Balsera et al. 2015). The introduction of agriculture in Andalusia and Catalonia is dated to the second half of the fifth millennium cal BC (PeñaChocarro and Zapata 2012), as in the Central Plateau (the Meseta) (for example, La Lámpara or La Revilla, Rojo et al. 2008). In the Pyrenean area, early evidence of agriculture has been recorded at Balma Margineda (Marinval 1995) and at some sites located in Huesca, such as Chaves or El Trocs (Rojo et al. 2013), dating to around the second half of the sixth millennium cal $\mathrm{BC}$, and highlighting a complex process of neolithisation in the Ebro valley. In this framework, the neolithisation process in the Cantabrian region appears to develop its own

1 BioArCh, University of York, Environment Building, Wentworth Way, Heslington, York YO10 5NG, UK

2 Arkaios Investigaciones, Mendigain 30, 20014 San Sebastián, Spain

3 Departamento de Prehistoria, Historia Antigua y Arqueología, Facultad de Geografía e Historia, Universidad de Salamanca, c/Cerrada de Serranos s/n, 37002 Salamanca, Spain

4 Wessex Archaeology, Portway House, Old Sarum Park, Salisbury SP4 6EB, UK

5 Departamento de Ciencias Humanas, Universidad de La Rioja, Edificio Vives C/Luis de Ulloa, s/n, 26004 Logroño, Spain

6 Sociedad de Ciencias Aranzadi, Zorroagagaina 11, 20014 Donostia-San Sebastian, Spain 
A
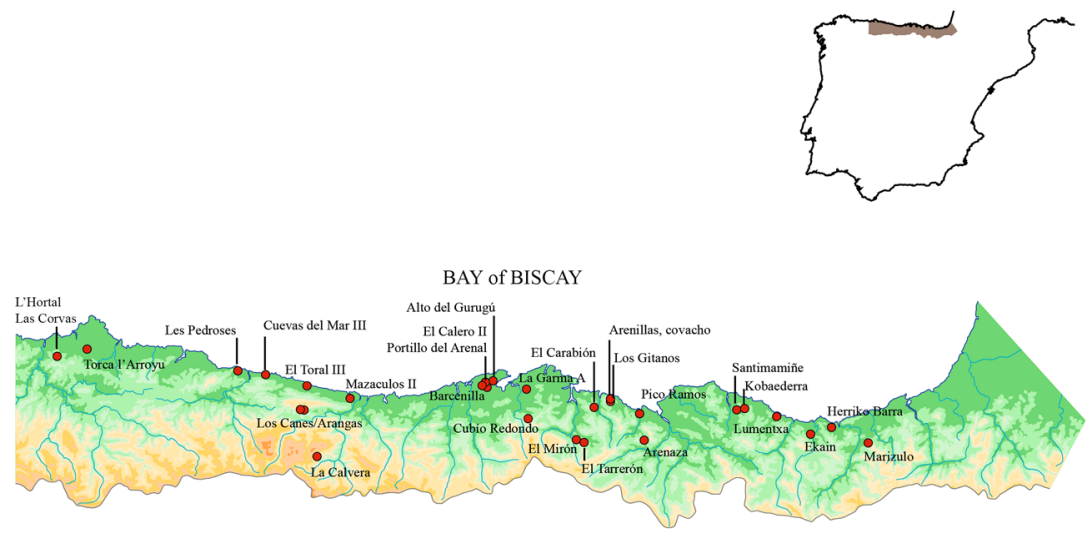

B $100 \mathrm{~km}$

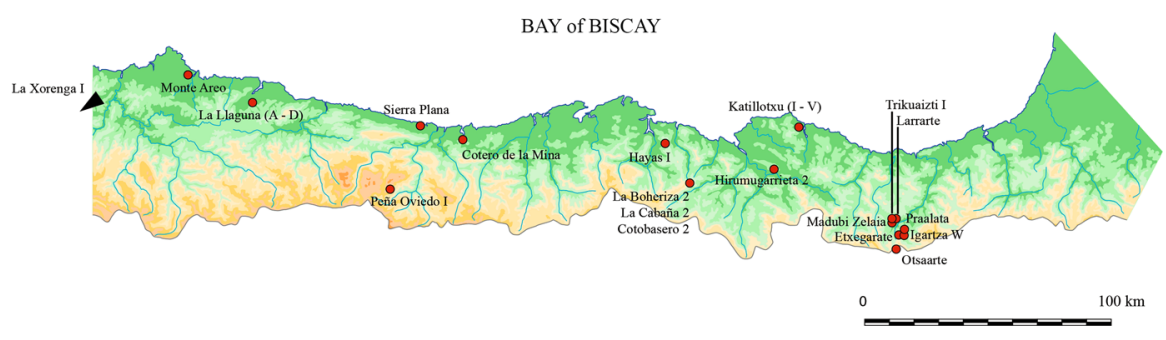

Fig. 1 a Archaeological sites (excluding megalithic structures) dated to the fifth and fourth millennium cal BC; $\mathbf{b}$ megalithic structures dated to the same period

dynamic and chronology (Fano et al. 2015), similar to the chronology of the Atlantic coast of Europe (Marchand 2014). The Cantabrian region is located in the north of the Iberian peninsula, between the Cantabrian mountains to the south, the Bay of Biscay to the north, and the rivers Nalón to the west and Bidasoa to the east (Fig. 1a). It comprises three administrative regions: (from east to west) northern Basque Country, Cantabria and Asturias.

Until the 1990s, research in the region concentrated on identifying the mere existence of the Neolithic, whose start was often assumed to date to the fourth millennium cal BC (González-Morales 1992, 1995a, 1996). However, the work of numerous researchers and research projects since the 1980 s has meant that the regional Neolithic is now better defined and has become an interesting research topic within the framework of the Iberian peninsula and the southwest European Atlantic coast. The 1980s and 1990s thus constitute a turning point in research on the first farming communities in the region, with the publication of the first general overviews of the Neolithic (see, for example, Alday and Mujika 1999; Arias 1991; de Blas 1983; Cava 1988; Díez-Castillo et al. 1995; González-Morales 1992, 1995a, 1996; Ontañón-Peredo 1995; Ruiz-Cobo 1991) and the megalithic phenomenon (see Arias 1990, 1997; Armendáriz 1987; de Blas 1987, 1997; Díez-Castillo 1991; González-Morales 1992; Serna 1997; Teira 1994). However, this latter phenomenon has played different roles in research in different parts of the region. In both Asturias and the Basque Country, a tradition of megalithic studies goes back to the late nineteenth 
century. In contrast, the important Palaeolithic record in Cantabria overshadowed not only megalithic studies but research into all late prehistory. Cantabria appeared to be a "noman's land' between two well-established megalithic groups, the Galician-Portuguese and the Basque-Pyrenean (Arribas and Molina 1984; de Blas 1983). This hiatus in the documentation of the central valleys consolidated the existence of two schools of thought and archaeological praxis, which led to the parallel development of an independent catalogue lexicon which is not explained by any real difference in the archaeological evidence (Teira 1995).

Recent research has made available a large body of information about the timing of the introduction of domesticated species in the region, the archaeological record at new sites, subsistence staples, and the appearance of new technologies, like pottery. It is now possible to appraise this archaeological information and the various hypotheses about the neolithisation process or processes that have been advanced for this region.

At the same time, the archaeological record is still deficient in many respects, with a virtual absence of open-air sites, limited evidence of funerary sites in the early Neolithic, and scarce information about domestic sites. Despite the recent excavation of representative sites for this period, like El Mirón (Straus and González-Morales 2012) and Los Gitanos (Ontañón-Peredo et al. 2013), references to open-air settlement are restricted to the sites of Herriko Barra (Basque Country) (Iriarte et al. 2005), Las Corvas and L'Hortal (Asturias) (Fernández-Mier and González-Álvarez 2013), and references to a possible hut at La Calvera in Cantabria (Díez-Castillo 1996). Although a very early date has been obtained at the site of Pareko Landa (López Quintana 2005), the ascription of the lithics to the initial Neolithic is not fully conclusive. In summary, the information provided by these sites taken together is limited and does not aid in an interpretation of the forms of subsistence or the population patterns of the first farming communities in the region.

In recent years, the number of Neolithic deposits has increased considerably, and longknown sites like Santimamiñe, Arenaza and Lumentxa have been joined by new locations such as Los Gitanos, El Mirón, Pico Ramos and Kobaederra (see supplementary Appendix and Fig. 1a, b). This paper reappraises the information about the sites attributed to this period, including data about the sites themselves (assessment of the archaeological deposit), organic remains (fauna and flora), and artefacts (lithic and pottery remains), in an assessment of the impact of the farming economy in the region (including the immediate effects of its initial appearance in the fourth millennium cal BC) and its influence on the social sphere. The available archaeological evidence for the study and analysis of the neolithisation process or processes has been summarised in order to present a reappraisal and systematisation of the period and advance a series of hypotheses to explain one of the most important topics in European prehistory.

\section{Chronology and Diachrony of the Process(es)}

The currently available information about the timing of the introduction of the farming economy in the Iberian peninsula indicates a chronological difference between the Mediterranean basin and northern Spain, part of a complex archaeological panorama with varying patterns in the adoption of the Neolithic way of life (Balsera et al. 2015; Isern et al. 2013).

A recent reassessment of the published dates in the Cantabrian region for the period 9500-2500 cal BC has brought together a large number of determinations for this time 
span, of which over 50\% correspond to sites that are, or are presumed to be, Mesolithic (Fano et al. 2015). In general, the publication of these dates was defective, with very limited descriptions of the samples, and a lack of taxonomical identification or data about their provenance-aspects that should be made clear in the publication of radiocarbon determinations (Wood 2015).

The available chronological information for the fifth-fourth millennia cal BC in northern Spain comes from 53 sites, which provide heterogeneous and sometimes imprecise information about the provenance of the samples. A total of 121 dates (Supplementary Index) have been obtained from different archaeological sites (Fig. 2a), by different measurement techniques and for varying types of sample (Fig. 2b). Most of the dates are for cave sites $(n=24)$ or megalithic structures $(n=23)$, and very few are from non-megalithic open-air sites $(n=6)$. The database includes the dates from the upper levels of some shell middens (Les Pedroses, Cuevas del Mar III and Cubío Redondo); materials on the surface of some sites (El Calero II, Portillo del Arenal and Alto del Gurugú); unrepresentative archaeological levels and isolated references (La Garma A, Lumentxa and El Toral III); and sites about which little information has been published as their study is still ongoing (Arangas, Santimamiñe, Pico Ramos and Ekain). They are generally of poor quality, since most were obtained from undetermined charcoal potentially subject to the 'old wood effect' and this clearly limits the chronological approximation (Fano et al. 2015), especially as regards the megalithic sites (Fig. 2b).

A

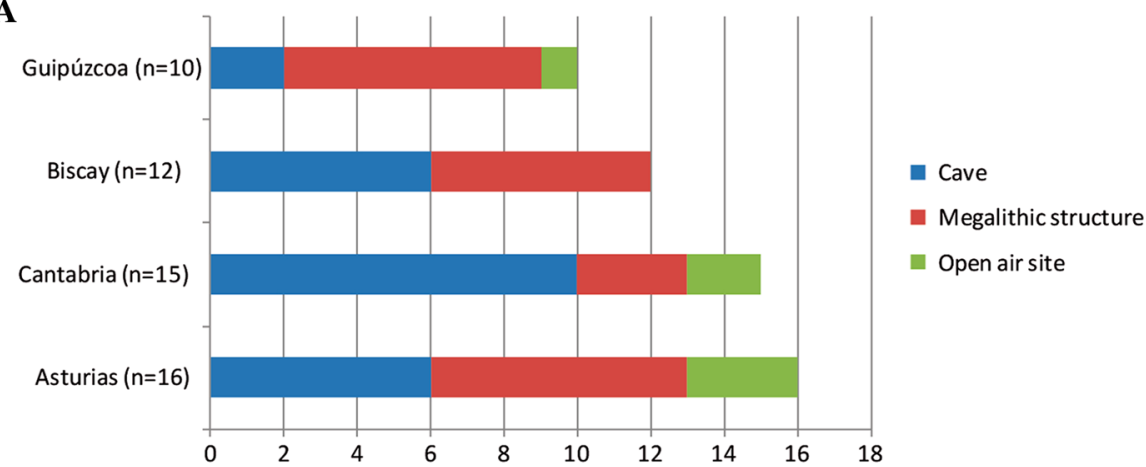

B

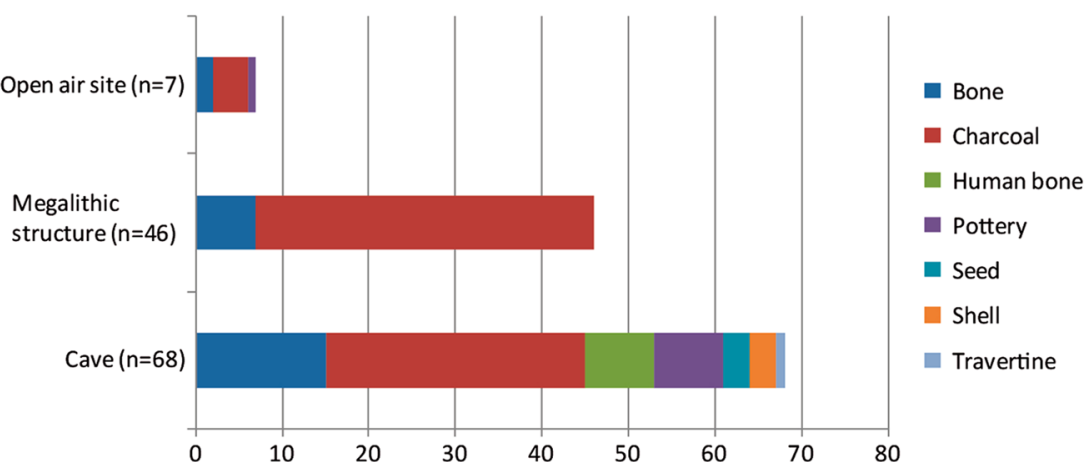

Fig. 2 a Number of dates classified by deposit type; b number of dates classified by type of sample 
Despite these limitations, the available dates reflect a complex panorama in the fifth millennium cal BC, in which the last Mesolithic sites overlap with the first evidence of farming practices. However, when this overlap is examined more closely, the presumably Mesolithic sites dated to the fifth millennium are concentrated in the western sector of the region, where sites reflecting early evidence of farming are lacking. These are found in the centre and east of the region, where comparatively fewer Mesolithic sites are known. This appears to suggest a possible 'neolithisation focal point' in the eastern part of the region, and a differential process, or rather processes, in the introduction of the farming economy in northern Spain.

This situation clearly changes in the late fourth millennium cal BC, when megalithic structures appear in a more or less homogeneous way (Fano et al. 2015), a phenomenon that continues, and even expands, during the third millennium cal BC (Mujika 2007), although the classic issues in the dating of megalithic sites must be noted (Bayliss et al. 2007). As well as megalithic sites, the fourth millennium also sees a few occupation levels and even evidence of open-air settlements.

The appearance of the megalithic phenomenon has been one of the criteria used to distinguish between an early and a developed stage in the Cantabrian Neolithic. Furthermore, later contexts, dated to the late fourth millennium or the beginning of the third have been labelled 'Late Neolithic'. The first is characterised by 'pre-megalithic' sites, the second includes the appearance and flourishing of megalithic sites, and the third would be marked by the Late Neolithic (Arias 1999). The latest archaeological evidence reflects continuity in the use of megalithic structures and even the building of new ones throughout the third millennium (Mujika 2007), and it is therefore difficult to determine a division between the 'apogee of Megalithism' and the Late Neolithic.

\section{The Last Hunter-Gatherer Societies: The Late 'Mesolithic'}

The available information reveals that the last hunter-gatherer societies knew an environment similar to today's (Fano 2004). Shell middens and levels rich in shells characterise the archaeological record in this period. They are found in large numbers in eastern Asturias (Fano et al. 2013) and western Cantabria, although little attention has been paid to the latter area (García-Escárzaga 2014). Research in recent decades has confirmed that the phenomenon of shell middens is not exclusive to this area: see, for example, J3 on the Basque coast.

The best-documented activity in the Mesolithic archaeological sites is shellfish gathering, characterised by the collection of a larger number of species and the use of other parts of the shore-for example when collecting goose barnacles-than in previous periods. Intensification, or anthropic pressure, has been given as the reason for the decrease in the size and age of some the species gathered, but other explanations, such as environmental factors, have also been proposed (Álvarez-Fernández et al. 2011; Álvarez-Fernández et al. 2013; Álvarez-Fernández et al. 2014a, b; Gutiérrez-Zugasti 2009a, 2011a, 2011b).

The few ${ }^{16} \mathrm{O}-{ }^{18} \mathrm{O}$ isotope studies and analyses of mollusc growth lines indicate that shellfish gathering was a seasonal activity, mainly carried out in autumn and winter (Deith and Shackleton 1986; Craighead 1995; Bailey and Craighead 2003). The exploitation patterns suggest that shellfish were collected mainly on rocky shores, although typical estuary species are also found (Álvarez-Fernández 2013a, 2013b; Álvarez-Fernández et al. 
2013; Gutiérrez-Zugasti 2009a, 2009b). Fishing was also practised, with an increase in the capture of marine species. These include pelagic species-previously absent from the archaeological record-such as sardines (Sardina pilchardus), anchovies (Engraulis mordax) and mackerel (Trachurus trachurus) (Fano et al. 2013). Taphonomic observations of recent finds confirm the capture and processing of marine species (Álvarez-Fernández 2015).

The meat of ungulates also formed part of the diet of Mesolithic groups, as attested by faunal assemblages and taphonomic studies. Red deer predominates in terms of number of remains, although it was not always the taxon providing the most calories, as in the case of the bovines at Mazaculos (Álvarez-Fernández and Altuna 2013; Altuna and Mariezkurrena 2012; Marín and González-Morales 2009). Recent studies have confirmed that species adapted to the Holocene environment, like roe deer and wild boar, as well as the occasional carnivore, were also hunted.

Climate amelioration in the Holocene and the spread of mixed deciduous forest widened the range of wild plant resources that could be consumed. Wild nuts and fruits such as hazelnuts, acorns and Rosaceae fruits (such as apples and rowanberries) must have played a major role in the diet of the last hunter-gatherer societies, as they were abundant, predictable, and could be stored (Uzquiano 1995; Zapata 2000). Continental snails (particularly Cepaea nemoralis) were probably another source of food (Álvarez-Fernández et al. 2013; Aparicio 2001; Gutiérrez-Zugasti 2009a).

Despite the increase in palaeoeconomic information, it is still difficult to calculate the relative contribution of each food type to the diet, especially when, due to taphonomic biases, some subsistence practices, such as gathering wild fruits, must be under-represented in the archaeological record, whereas others, such as shellfish gathering, are probably overrepresented. However, some stable isotope data $\left(\delta^{13} \mathrm{C}\right.$ and $\left.\delta^{15} \mathrm{~N}\right)$ obtained from the collagen of several human remains in the regions (Arias 2005) reflect similar amounts of terrestrial and marine protein in the diet. (It should be noted that palaeodietary data from sites in Navarra to the east and León to the west [e.g. Aizpea: Zapata 2000; La Braña: Arias and Schulting 2010] are not included as relevant comparators here due to the fundamentally different nature of these inland environments.)

It has often been pointed out that lithic, bone and antler hunting implements are very scarce at Asturian deposits (Arias and Fano 2009; Fano 2004; González-Morales 1982). The improbability of their appearance in shell-middens, and the use of perishable raw materials (such as wood) are often put forward as explanations for this scarcity. Indeed, the contrast between Asturian tool kits, characterised by implements made from cobble-stones, and those from other Mesolithic sites in the region, where geometric microliths occur, is noteworthy. However, new finds, such as the ensemble of lithic armatures (circle segments, triangles, trapezia, etc.) at El Mazo are helping to reduce this contrast (Gutiérrez-Zugasti et al. 2014; Arias and Fano 2009).

Recent research has demonstrated that Mesolithic groups also used gastropod and bivalve shells as tools, especially for making objects with plant matter (probably nets, ropes, etc.) (Cuenca 2013). Regarding the oft-debated function of the Asturian picks, the results of recent functional studies have proved to be consistent with their use for gathering molluscs, such as Patella sp., from rocky substrates (Clemente et al. 2010). Additionally, data on lithic raw material procurement generally suggest a small radius of mobility (Arias et al. 2009a, b; Cava et al. 2007; Tarriño 2006), although examples of raw materials from distant areas are also found. However, contacts between the Upper Ebro valley and the northern coast are of special interest (Álvarez-Fernández 2006). 
As in previous periods, most archaeological deposits are located in caves and rockshelters, and open-air sites are rare (Fano 2004). The population pattern is basically coastal, even though some sites are a considerable distance from the shore. The best-known group of deposits is in eastern Asturias (Fano 1998), and these are not located strictly on the coastline, especially when the effects of the post-glacial sea-rise are taken into account. The transportation of resources, both marine and terrestrial, to those sites demonstrates the existence of areas of habitation in the caves or in areas connected with them, as has been proposed for Mazaculos cave (González-Morales et al. 1980); el Mazo and El Toral III (Gutiérrez-Zugasti et al. 2014; Noval 2013); and El Alloru (Arias et al. 2015, in press).

\section{Evidence of Change: The Neolithisation Process and Its Impact in the Region}

\section{Agriculture and Stockbreeding: The New Economic Basis}

\section{Earliest Evidence of Crops}

The first Neolithic crops in the Iberian peninsula are incontestably attested in plant macroremain evidence around the mid sixth millennium cal BC, on both the Mediterranean and Atlantic coasts and in the North Meseta, at sites such as Cova de les Cendres, La Falguera, Mas d'Is, Can Sadurní, El Toro, La Lámpara, Lapiás das Lameiras, La Revilla del Campo, Los Mármoles, Los Murciélagos, Nerja and S. Pedro de Canaferrim (see Fig. 3; Antolín and Buxó 2012; López-Dóriga and Simões 2015; Peña-Chocarro 2007; Stika 2005; Zapata et al. 2004; Zapata et al. 2005). The exceptionally preserved waterlogged site of La Draga, dated in the late sixth-early fifth millennium, has provided complementary evidence on plant remains and agricultural tools (Antolín et al. 2015). The direction of early Neolithic introduction in the Iberian peninsula, either from France and Central Europe or other Mediterranean areas such as Italy or North Africa, is the subject of debate (e.g. Antolín et al. 2015; Antolín and Buxó 2012; Zapata et al. 2004). The available evidence suggests that by the second half of the sixth millennium a diverse agriculture based on the cultivation of naked and hulled wheats (Triticum aestivum/durum/turgidum, T. dicoccum and T. monococcum) and barley (Hordeum vulgare), legumes such as pea

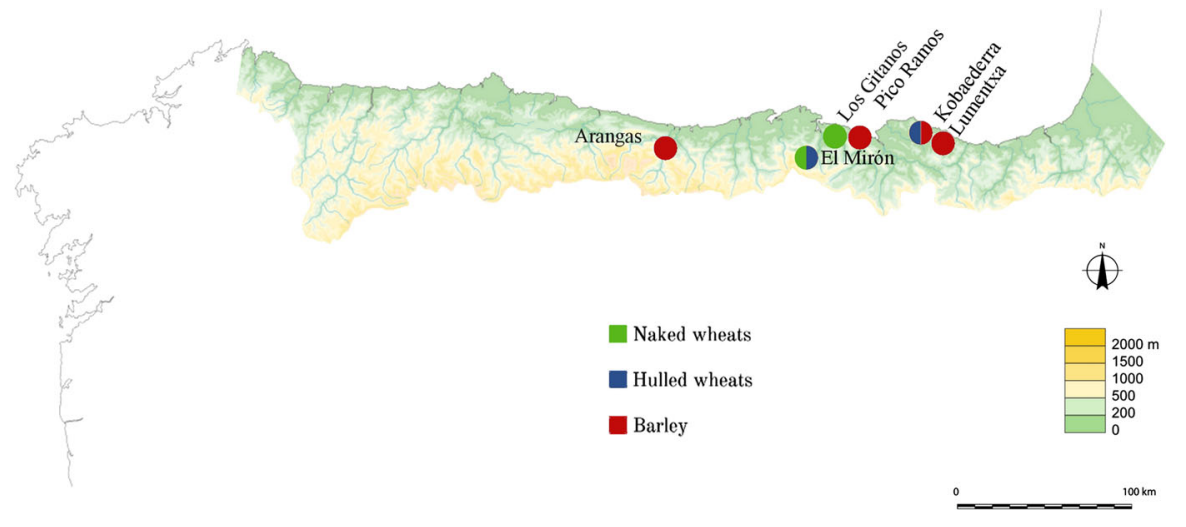

Fig. 3 Neolithic cereal crops in the Cantabrian region 
(Pisum sativum), lentil (Lens culinaris), broad bean (Vicia faba), common vetch (Vicia sativa) and grass pea (Lathyrus sativus), and occasionally flax (Linum usitatissimum) and opium poppy (Papaver somniferum).

In northern Spain, several determinations of cereal pollen-which must be viewed with caution due to the impossibility of absolute discrimination of pollen from wild grasses and cereals (Behre 2007) - have been made at various sites from the second half of the sixth millennium onwards: O Reiro (La Coruña) (López-Sáez et al. 2010) and other peat bogs in Galicia and Asturias (López-Merino et al. 2010), and at the archaeological sites of Los Gitanos (Cantabria) (Ontañón-Peredo et al. 2013) and Herriko Barra (Basque Country) (Iriarte et al. 2005). However, incontestable evidence for the first domestic crops in the Cantabrian region, as provided by plant macroremains, is scant and comes from just four sites with charred preservation of plant remains and layers dated from the middle of the fifth millennium onwards (Kobaederra, Pico Ramos and Lumentxa in Biscay, and El Mirón in Cantabria) (Zapata 2002; Zapata et al. 2004; Peña-Chocarro et al. 2005a; Zapata et al. 2007). The scarcity of contexts dated to the sixth millennium might be behind this apparent delay in the introduction of agriculture (Zapata et al. 2007). If reliable dates for early Neolithic contexts in the Cantabrian region are in general very scarce (see above), they are even scarcer for sites with non-woody plant macroremains. To put it in another way, of those few early Neolithic sites with certain dates, only a few, namely Pico Ramos, El Mirón, and Kobaederra (Peña-Chocarro et al. 2005b; Zapata 2002; Zapata et al. 2007) have had archaeobotanical sampling and analyses carried out.

The early Neolithic crops in the Cantabrian region, as attested by this plant macroremain evidence, are four allochthonous cereal species: emmer (Triticum dicoccum); einkorn (Triticum monococcum); common or bread wheat (Triticum 'nudum', i.e. Triticum aestivum/durum/turgidum); and barley (Hordeum vulgare) (Peña-Chocarro et al. 2005a). The absence of evidence for pulse exploitation (with the exception of a large legume seed from Kobaederra, which might be cultivated: Zapata 2002) is thought to be linked to sample poverty rather than necessarily an actual absence from the Neolithic crop package (Zapata 2005). Given the present archaeobotanical data, a relatively diverse assemblage of plant domesticates is thought to have been progressively (and tentatively) adopted by local populations (Zapata et al. 2004), although the arrival of foreign populations with them or the existence of specialised or seasonal sites without plant domesticate processing activities cannot be ruled out (Zapata 2002). The potential pathways of crop introduction are also under debate, but southern France and the northern Meseta seem likely candidates (Zapata and Peña-Chocarro 2005; Zapata et al. 2007).

In the fourth millennium, evidence for domestic crops is also sparse. The charred archaeobotanical assemblage of Arangas adds the naked variety of barley (Hordeum vulgare var. nudum) to the assemblage of Neolithic crops cultivated in the region (Arias et al. 2013). Although barley was already present in the fifth millennium, only the hulled variety (Hordeum vulgare var. vulgare) was definitely attested at Lumentxa (Zapata 2002). Another context that has provided domesticate remains (although scarce) is Los Gitanos (Ontañón-Peredo et al. 2013), with Triticum sp. and Triticum 'nudum'.

Therefore, the first agriculture in the Cantabrian region is characterised by the simultaneous introduction of naked and hulled varieties of wheat and barley (Triticum dicoccum, Triticum monococcum, Triticum 'nudum', Hordeum vulgare), whilst other typically early Neolithic domesticates, such as flax (Linum usitatissimum), opium poppy (Papaver somniferum) and legumes (Lathyrus sativum, Lens culinaris, Pisum sativum, Vicia sp.) are absent (see Table 1). However, these other domesticates have less chance of surviving in charred assemblages and therefore their absence could be due to unfavourable differential 
Table 1 Major exploited taxa and agricultural crops present at Neolithic archaeological sites in the Cantabria region between the fifth and fourth millennia cal BC

\begin{tabular}{|c|c|c|c|c|c|c|}
\hline & $\begin{array}{l}\text { Pico } \\
\text { Ramos }\end{array}$ & $\begin{array}{l}\text { El } \\
\text { Mirón }\end{array}$ & Kobaederra & Lumentxa & Arangas & $\begin{array}{l}\text { Los } \\
\text { Gitanos }\end{array}$ \\
\hline Hordeum vulgare & $\sqrt{ }$ & & $\sqrt{ }$ & & $\sqrt{ }$ & \\
\hline Hordeum vulgare var. nudum & & & & & $\sqrt{ }$ & \\
\hline $\begin{array}{l}\text { Hordeum vulgare var. } \\
\text { vulgare }\end{array}$ & & & & $\sqrt{ }$ & $\sqrt{ }$ & \\
\hline Triticum 'nudum' & & $\sqrt{ }$ & & & & $\sqrt{ }$ \\
\hline Triticum dicoccum & & $\sqrt{ }$ & $\sqrt{ }$ & & & \\
\hline Triticum monococcum & & $\sqrt{ }$ & & & & \\
\hline Corylus avellana & $\sqrt{ }$ & $\sqrt{ }$ & $\sqrt{ }$ & & $\sqrt{ }$ & $\sqrt{ }$ \\
\hline Quercus sp. & & $\sqrt{ }$ & $\sqrt{ }$ & $\sqrt{ }$ & $\sqrt{ }$ & $\sqrt{ }$ \\
\hline
\end{tabular}

preservation as compared to cereals. Given the scarcity of the evidence, it is difficult to infer whether this agricultural panorama is a result of the current imperfectly-known record, or of the particularities of the first agriculture in the region.

\section{Stockbreeding: Emergence and Consolidation}

The last hunter-gatherer groups continued to live in northern Spain at a late date when in other nearby areas, such as southern France, husbandry was already practised. The presence of domestic dogs at hunter-gatherer sites (Altuna 1994; Altuna and Mariezkurrena 1985; Vigne 2005) confers a special status on this species. In contrast, evidence of husbandry at sites like Arenaza, Los Gitanos, El Mirón and Kobaederra is an indicator of an innovation defining early Neolithic levels.

At the first of these sites, the first evidence of husbandry has been dated to the fifth millennium cal BC in the lower level of the sequence, in which domesticated animals are well represented (Altuna 1980; Arias and Altuna 1999). The archaeozoological study of Los Gitanos (Altuna and Mariezkurrena 2009) reflects a mixed economy in the oldest parts of the sequence, where a predominant exploitation of wild resources is complemented with livestock. This trend is gradually reversed in more recent levels (sub-Level A2), where the percentage of domestic species reaches $51.4 \%$, roughly equalling the proportion of wild fauna. Then, in sub-Level A1, attributed to the Chalcolithic, domestic livestock is more abundant than wild species (Ontañón-Peredo et al. 2013).

Similarly, at El Mirón, Level 10, attributed to the mid fifth millennium cal BC, is clearly dominated by domestic livestock, with a percentage of $66.8 \%$, significantly larger than that of wild ungulates (Altuna and Mariezkurrena 2012). The most abundant domestic taxa are ovicaprines $(90.1 \%)$, while cattle and swine only reach $6.3 \%$ and $3.6 \%$ respectively. In other parts of the cave with levels attributed to the Neolithic (Levels 303-303.3), the percentage of domestic species increases, still with a total predominance of ovicaprines. In more recent chronologies (Levels 9.8, 9.7, 9.6 and 9) the percentage of domestic ungulates reaches $95 \%$. While ovicaprines still predominate, their percentages decrease in favour of cattle. At a later date (Level 8, in the late fifth and early fourth millennia cal BC), the dominance of domestic species, and the ovicaprines amongst them, becomes even clearer. 
Another site with an early Neolithic sequence is Kobaederra (Levels IV-III). The archaeozoological study (Altuna and Mariezkurrena 2009) showed a predominance of domestic species $(70.3 \%)$ over wild ungulates $(28.5 \%)$. The livestock consisted mainly of ovicaprines $(82.4 \%)$, followed by cattle $(14.8 \%)$ and swine $(2.8 \%)$.

The only open-air site documented for the first half of the fifth millennium cal BC, Herriko Barra, lacks domestic animals; authors attributing this site to the Neolithic have explained this absence by interpreting it as a specialised hunting camp (Iriarte et al. 2005).

The archaeological evidence for the fourth millennium is very variable in its quality. This is owing to the secondary (redeposited) position of the archaeological deposits at Torca l'Arroyu (Jordá et al. 2008); the existence of remains of different chronologies in Stratigraphic Unit 3 at El Toral III (Noval 2013); the limited archaeozoological information from other sites, such as Barcenilla (Muñoz et al. 2013); and the stratigraphic issues at such sites as Arenaza (Apellániz and Altuna 1975). At this latter site, ovicaprines predominate in Level IC1 (Altuna and Mariezkurrena 2009).

Domestic species were documented in Level A2 at Mazaculos II, all of them identified from infantile individuals, and of secondary importance compared with hunting (Marín and González-Morales 2009), despite the late chronological attribution of this level. At the other end of the region, the archaeozoological record at Cueva de Marizulo equally reflected a predominance of wild ungulates over domestic species (Álvarez-Fernández and Altuna 2013). The latter are represented by domestic dog (Canis familiaris) and sheep (Ovis aries) associated with a burial in Level I (Laborde et al. 1965, 1966, 1967). The absence of faunal remains at the open-air sites of L'Hortal and Las Corvas in Asturias and La Calvera in Cantabria precludes consideration of this type of resource at open-air settlements.

Despite the scantiness of the archaeological record, the introduction of domestic species attested at El Mirón is not so clear at contemporary sites like Los Gitanos (sub-Level A4A3) (Ontañón-Peredo et al. 2013) or even in levels assigned a later chronology, like Arenaza Level IC1 (Apellániz and Altuna 1975), Los Gitanos (sub-Level A2) and Mazaculos II (Level A2) (Marín and González-Morales 2009). Coetaneous sites in the southern Basque Country, like La Renke (Altuna and Mariezkurrena 2001) and Los Cascajos (Altuna and Mariezkurrena 2009) display an evident predominance of cattle. In contrast to these open-air settlements, caves such as Zatoya, Mendandia (Castaños 2005), Los Husos (Altuna 1980) and Peña Larga (Castaños 1997) either have not yielded domestic livestock or their faunal record is dominated by ovicaprines. This has prompted the hypothesis that the ovicaprines in caves in northern Spain reflect the use of the caves as sheep pens in the vicinity of sites in lowland areas or near rivers, which may have been the location of permanent dwellings where cattle were kept. However, this hypothesis cannot yet be proved, since no settlements have been documented in valley areas.

\section{The Persistence of 'Traditional Strategies'}

\section{Wild Plant Gathering}

For the Holocene - both before and after the introduction of plant domesticates - the main evidence for the exploitation of wild plants in the Cantabrian region comes from remains of hazelnut (Corylus avellana) shell, although remains of acorn (Quercus sp.) cotyledons, and fruits from the rose family (Rosaceae)—such as crab apple (Malus sylvestris), and whitebeam, wild service tree or rowan (Sorbus sp.) —are also relatively abundant (Arias et al. 2013; Ontañón-Peredo et al. 2013; Zapata 2000). These products, of mainly nutritional interest, have very particular seasons for gathering: pomes towards the end of the 
summer and nuts during autumn (with small variations from year to year). If eaten fresh, plant remains from these taxa might serve as indicators of seasonal occupation activities at certain sites. They are, however, products with good storage qualities, whose storage-life can be prolonged to about a year in ideal circumstances (Cunningham 2005; Riddervold and Ropeid 1988). The ubiquity of hazelnut remains in the archaeobotanical record of Holocene sites throughout temperate Europe (Holst 2010), as well as in northern Spain, has been argued to result from a combination of factors: the abundance of hazelnuts and their frequent exploitation by different populations, and their propensity to survive charring and be recovered by particular techniques (Zapata 2000). The relative abundance of hazelnuts cannot be compared with that of other resources, as their shells are more likely to become carbonised and be recovered than other types of remains (Jones 2000; Score and Mithen 2000), and some recovery techniques might select and over-represent specific remains (Scaife 1992). Even so, the abundance and ubiquity of hazelnuts is undeniable and needs to be better understood (López-Dóriga 2015).

In addition to remains of hazelnuts, acorns and pomes, usually recovered where no special retrieval techniques for plant macroremains have been employed, other less conspicuous non-woody plant macroremains have been abundantly recovered from sites in which systematic flotation of the sediment has been carried out, highlighting the importance during the Neolithic of wild plant exploitation practices for a variety of potential food, medicinal or technological purposes (Table 2).

Furthermore, charcoal analyses have indicated the exploitation of several woody taxa, many of which provide fruits and nuts of economic interest in addition to wood for technological activities and fuel: white oaks (Quercus subgenus Quercus), pome bearing trees (Pomoideae), ash (Fraxinus sp.) and beech (Fagus sylvatica) (Ruiz-Alonso et al. 2010; Tapia et al. 2008). Use-wear analyses of shell tools evidence their probable use for processing plants on the basis of the similarities with experimental tools: a fragment of a cross-cut carpet shell (Ruditapes decussatus L.) from the Neolithic levels of Santimamiñe was probably used for processing of non-woody silica-rich plants (Cuenca et al. 2010; Cuenca et al. 2011).

To summarise, wild exploitation activities continued apparently unchanged after the introduction of domestic species. A similar pattern has been observed in the northeast of the Iberian peninsula, suggesting an intensification in the exploitation of resources, which would allow a sustainable sedentism (Antolín et al. 2015). Modifications to the year-round organisation of labour with regard to plant resources would be expected, as the new crops and fields would have to be prepared and tended throughout the year.

\section{Hunting}

There is evidence of continued hunting in northern Spain even at later dates, and at some sites it was the only form of animal subsistence, apart from shellfish, as explained below. At the site of Los Canes (Stratigraphic Unit 7), dated to the early fifth millennium cal BC, only wild fauna has been documented, mainly ibex (Capra pirenaica) and chamois (Rupicapra rupicapra), as well as red deer (Cervus elaphus), wild boar (Sus scrofa) and roe deer (Capreolus capreolus); no evidence of domestic species has been found (Arias 2002). In Cantabria, at Los Gitanos, hunted animals similarly predominate over domestic species (Álvarez Fernández et al. 2014a, b). Hunting at this site is represented by red deer $(86.8 \%$ ), followed by wild boar (9.4\%) and roe deer (3.8\%). In turn, at Cueva de El Mirón (Altuna and Mariezkurrena 2012) in the oldest Neolithic level (Level 10), a third of the faunal remains belong to wild ungulates and two thirds to livestock. Of the prey, red deer is by far the most abundant $(87 \%)$, followed by roe deer $(8.1 \%)$ and ibex $(4.9 \%)$. 
Table 2 Major exploited wild taxa present at Neolithic archaeological sites in the Cantabria region

\begin{tabular}{|c|c|c|c|c|c|}
\hline & $\begin{array}{l}\text { El } \\
\text { Mirón }\end{array}$ & Kobaederra & Lumentxa & Arangas & Los Gitanos \\
\hline \multicolumn{6}{|l|}{ Fruits } \\
\hline $\begin{array}{l}\text { Corylus avellana } \\
\text { Ficus carica }\end{array}$ & $\sqrt{ }$ & $\sqrt{ }$ & & $\sqrt{ }$ & $\begin{array}{l}\sqrt{ } \\
\sqrt{ }\end{array}$ \\
\hline Malus sylvestris & & & $\sqrt{ }$ & & \\
\hline $\begin{array}{l}\text { Quercus sp. } \\
\text { Rubus sp. }\end{array}$ & $\sqrt{ }$ & $\sqrt{ }$ & & $\sqrt{ }$ & $\sqrt{ }$ \\
\hline Sorbus sp. & & & & $\sqrt{ }$ & \\
\hline Rosaceae & & $\sqrt{ }$ & & & \\
\hline \multicolumn{6}{|l|}{ Herbs } \\
\hline Caryophyllaceae & $\sqrt{ }$ & & & & \\
\hline Compositae & & & & & $\sqrt{ }$ \\
\hline Carex sp. & $\sqrt{ }$ & & & & \\
\hline Cyperaceae & $\sqrt{ }$ & & & & \\
\hline Ericaceae & & & & & \\
\hline Erodium sp. & & & & & \\
\hline Luzula sp. & $\sqrt{ }$ & & & & \\
\hline Juncaceae & $\sqrt{ }$ & & & & \\
\hline Lolium sp. & $\sqrt{ }$ & & & & \\
\hline Gramineae & $\sqrt{ }$ & & & & $\sqrt{ }$ \\
\hline Trifoliae & & & $\sqrt{ }$ & & \\
\hline Leguminosae & $\sqrt{ }$ & $\sqrt{ }$ & & & \\
\hline $\begin{array}{l}\text { Potentilla sp. } \\
\text { Galium sp. }\end{array}$ & $\sqrt{ }$ & & & & $\sqrt{ }$ \\
\hline $\begin{array}{l}\text { Rumex sp. } \\
\text { Polygonaceae }\end{array}$ & $\sqrt{ }$ & $\sqrt{ }$ & & & $\sqrt{ }$ \\
\hline Veronica sp. & $\sqrt{ }$ & & & & \\
\hline Umbelliferae & $\sqrt{ }$ & & & & \\
\hline
\end{tabular}

At Kobaederra (Altuna and Mariezkurrena 2009) hunted prey makes up 28.5\% of the faunal assemblage; red deer is again the most important $(74.7 \%)$, followed by wild boar (17.8\%), roe deer $(7.1 \%)$ and horse (Equus caballus) $(0.4 \%)$.

As stated above, at Herriko Barra (Mariezkurrena and Altuna 1995) only wild ungulates and carnivores were documented. Once more, red deer predominates (93\%). The other prey were wild boar, roe deer and aurochs (Bos primigenius). This is therefore a site specialising in hunting red deer, a pattern found at earlier times in the region.

This predominance of red deer is equally seen at Arenaza (Altuna 1980), where hunting accounts for $20.6 \%$ of the large mammal remains. Of these, $91.5 \%$ belong to red deer and the other $8.5 \%$ to wild boar, roe deer and aurochs. 
Together with the scant domestic fauna, Level A2 at Mazaculos II reflects the importance of hunting at a fourth millennium site. In the number of remains, red deer is followed by roe deer, swine, cattle and ovicaprines. However, cattle would have supplied the largest amount of meat (Marín and González-Morales 2009).

In Cueva de Marizulo at the eastern end of the region, wild ungulates, especially red deer, also predominate over livestock (Álvarez-Fernández and Altuna 2013). Hunting would be slightly more important than at Los Gitanos, although red deer is less important. This prey constitutes $60.9 \%$ of the wild species, the rest being wild boar (24.4\%); roe deer (11.8\%); ibex (2.5\%); and chamois (0.4\%) (Álvarez-Fernández et al. 2014a).

\section{Marine Resources}

The archaeological record currently suggests the sustained presence of marine resources in the subsistence of human groups once the farming economy had been introduced to northern Spain. This is clearly shown by the high density of molluscs in deposits dated to the fifth and fourth millennia cal BC, including such sites as Cuevas del Mar III (Fano 2004); Mazaculos II (González-Morales 1995b); Barcenilla (Muñoz et al. 2013); Los Gitanos (Álvarez-Fernández et al. 2014a); Arenillas (Bohigas and Muñoz 2002; GutiérrezZugasti 2009a); Pico Ramos (Zapata et al. 2007); Kobaederra (Gutiérrez-Zugasti 2009b); and Santimamiñe (Gutiérrez-Zugasti 2011c).

Archaeomalacological studies show a predominance of molluscs gathered on rocky shores-such as limpets (Patella sp.), top shells (Phorcus lineatus) and, to a lesser extent, mussels (Mytilus sp.) and oysters (Ostrea sp.) —rather than species inhabiting sandy and muddy substrates, like the bivalves Ruditapes decussates and Scrobicularia plana, and razor shells (Solen sp.). This tendency is observed both at sites dated to the fifth millennium cal BC (Cuevas del Mar III, Los Canes SU7, Arenillas Level 0, Los Gitanos subLevels A4 and A3, Pico Ramos Level 4 and Kobaederra Levels IV and III) and in later deposits (Mazaculos II Levels A2 base and top, Los Gitanos sub-Level A2, Barcenilla Levels 4 and 3 and Santimamiñe Layers Slm and Lsm) (Table 3).

The site of Barcenilla, recently published, reflects continuity in the exploitation of marine molluscs between Level 5, attributed to the Mesolithic, and the Neolithic Levels 4 and 3 (Table 3). In these levels, molluscs from rocky shores predominate, although certain changes are seen in the proportions of the taxa. Whereas in the Mesolithic the main taxa are mussels, limpets and top shells, in the Neolithic levels, limpets increase in abundance, followed by mussels and top shells. The Patella genus is represented above all by $P$. depressa, again followed by $P$. vulgata and P. ulyssiponensis (Fig. 4). The same continuity is seen in the sequence at Los Gitanos throughout the fifth and third millennia cal BC (Table 3). Molluscs from rocky shores predominate, in the form of limpets and top shells, with high percentages in all sublevels (Table 3). The same three species appear in three levels: $P$. depressa predominates (always $>50 \%$ ), followed by $P$. vulgata and then $P$. ulyssiponensis. The order of the last two is only inverted in sublevel A4.

In contrast, at the sites in the area around the Urdaibai estuary (Santimamiñe and Kobaederra), species from sandy substrates are relatively more common. Thus, at the site of Kobaederra and Santimamiñe, the taxon Scrobicularia plana is the most represented (Table 3).

So we can see that not only do several archaeological sequences show that the exploitation of the marine environment did not end in the fifth and fourth millennia cal BC, but many of them, like Mazaculos, Barcenilla and Santimamiñe, are veritable shell-middens, reflecting the continuity of traditional subsistence practices in the fourth millennium. 


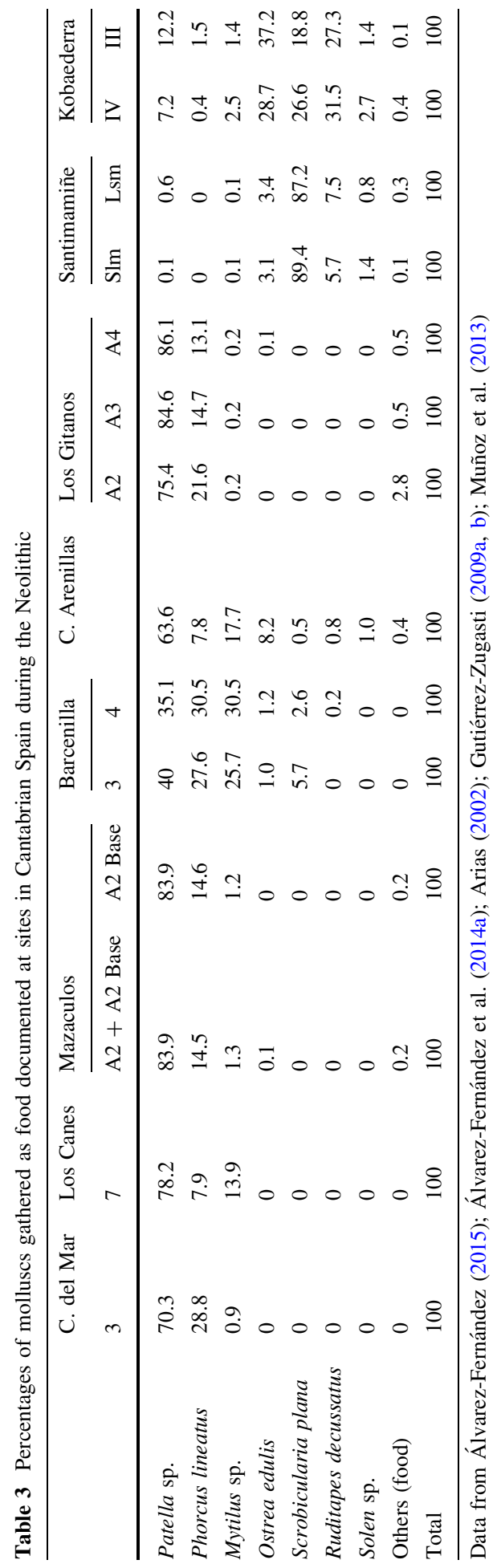



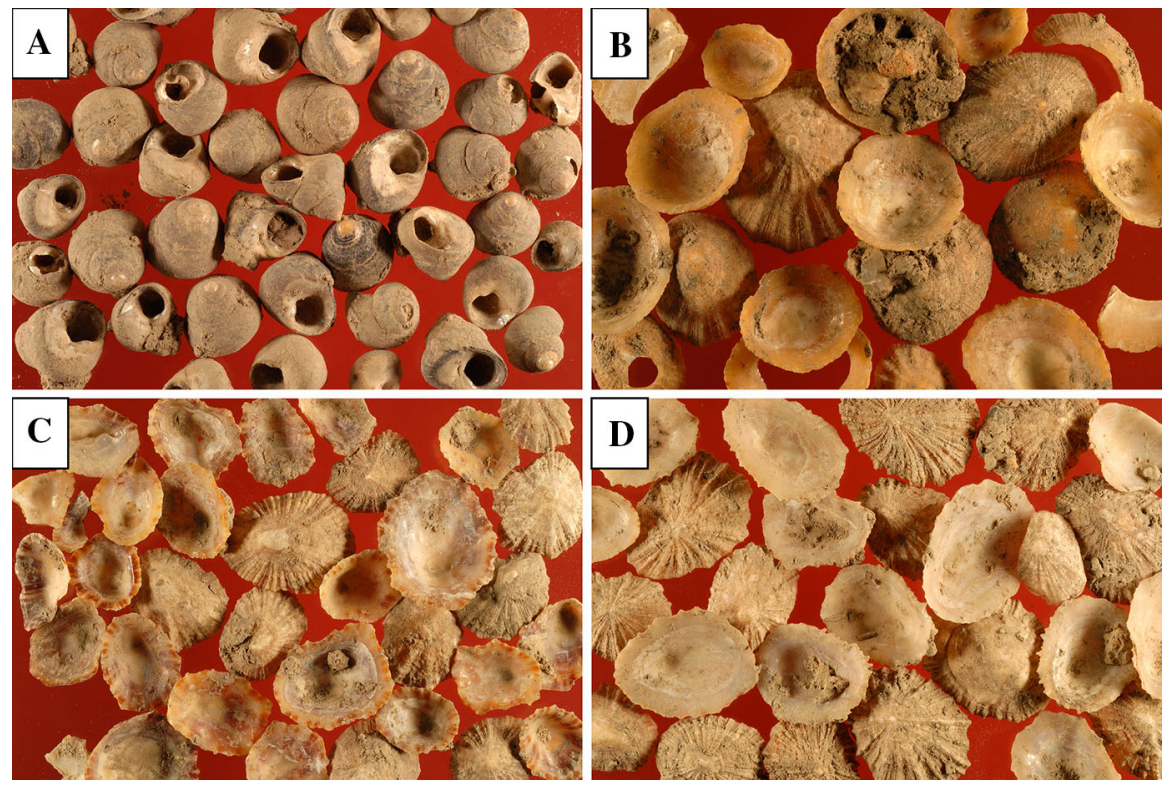

Fig. 4 Marine shells from the Neolithic of Los Gitanos Cave (Cantabria, Northern Spain): a Phorcus lineatus; b Patella vulgata; c Patella depressa; d Patella ulyssiponensis

This use of the marine environment is not only shown by the presence of molluscs, but also by remains of crustaceans, echinoderms, sea birds, fish and marine mammals. The most common crustaceans are represented by the pincers of crabs and the plates of the goose barnacle Pollicipes pollicipes (Fig. 5). Crab remains (Pachygrapsus marmoratus, Eriphia spinifrons, Xantho sp.) have been documented in the three Neolithic levels at Los Gitanos (Levels A2, A3 and A4) (Álvarez-Fernández et al. 2010; Álvarez-Fernández et al. 2014a) (Fig. 5). At Arenillas, the most abundant species (84\%) is Pachygrapsus marmoratus, although Carcinus maenas, Eriphia verrucosa, Portunidae and Cancer pagurus have also been documented (Gutiérrez-Zugasti 2009a). The low numbers of crabs and barnacles at this site suggest that they were foraged opportunistically during molluscgathering, as also would have occurred at some Mesolithic sites where remains of crabs (Poza l'Egua) and barnacles (J3) have been found. This same trend has been observed in more recent deposits (sub-Level A1 at Los Gitanos) (Álvarez-Fernández 2015).

The remains of echinoderms equally indicate the exploitation of the marine environment. They are generally found in small quantities, and large numbers have been recorded only at Arenillas (Gutiérrez-Zugasti 2009a) and Los Gitanos (sub-Levels A2, A3 and A4), but it cannot be confirmed that the animals were consumed by humans (Álvarez-Fernández et al. 2014a).

Data on the consumption of sea birds comes only from Level C at Herriko Barra, where 61 osseous remains of several birds have been recorded (Uria aalgae, Fratercula arctica, Alca torda, Pinguinus impennis, Fulmaurus glacialis, Puffinus puffinus and Risa tridactila). Of these, a Pinguinus impennis bone displays cutmarks, while five remains of other species (two of Uria aalgae, and one each of Fratercula arctica, Alca torda, and Fulmaurus glacialis) appear to have been burnt (Elorza 1993). The only marine mammals 

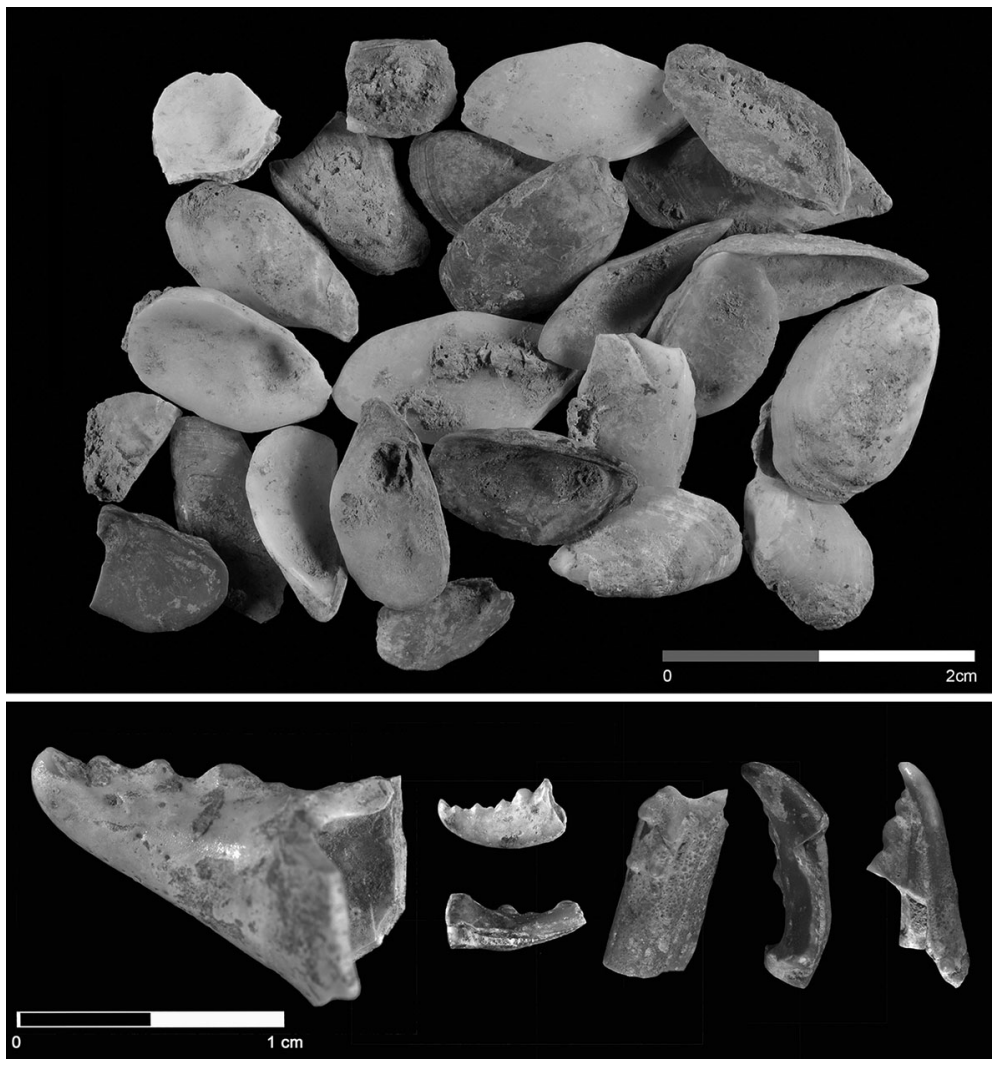

Fig. 5 Los Gitanos, Neolithic levels. Top: plates of Goose barnacle (Pollicipes pollicipes); bottom: crab claws (Eriphia spinifrons and Xantho sp.)

dated to this period also come from Level $\mathrm{C}$ at Herriko Barra, where two vertebrae and a hemal bone of a juvenile beaked whale (perhaps Ziphius cavirostris) were found. The animal may have become beached and its meat consumed by the human groups (ÁlvarezFernández 2015).

Few fish remains have been found. In the same Level at Herriko Barra, three remains possibly of the family Sparidae have been found (Álvarez-Fernández 2015) and further remains were documented in the three Neolithic levels at Los Gitanos: two remains of Diplodus cf. vulgaris, four of the family Labridae, four of the family Gobiidae and two of Gaidropsarus sp. (Álvarez-Fernández et al. 2014a). A Merlucius merlucius bone was cited in Level Slm at Santimamiñe (Roselló and Morales 2011). Species whose habitats are rocky coasts or estuaries indicate that fishing took place near the shore, while open-water species may have been caught when they approached the coast at the time of laying their eggs.

Mollusc shells not only provide evidence of the consumption of those resources, they were also used as tools, as documented in the Neolithic levels in Santimamiñe (Cuenca 2011). More often, however, they were used to make objects of adornment. The two species used in this way in the Neolithic are: Nassarius reticulatus at Mazaculos (Level A2 
base, one specimen) (Gutiérrez-Zugasti 2009a) and Los Canes (SU 7, one specimen) (Álvarez-Fernández 2006); and Trivia sp., which has been documented at Los Canes (SU 7) with three specimens (Álvarez-Fernández 2006), one specimen at Los Gitanos (subLevel A3) (Álvarez-Fernández et al. 2014a) and one more at Barcenilla (Level 3) (Muñoz et al. 2013). The use of these species to make beads has been also documented in earlier (Los Canes, Poza l'Egua, La Garma A and El Truchiro) and later (Arangas B and Pico Ramos 3) chronologies (Álvarez-Fernández 2015).

\section{Isotopic Record: Reconstructing the Palaeodiet}

Palaeodiet analysis is another way to assess continuity in subsistence practices in prehistoric societies. However, the information available about this type of study in northern Spain is as yet very limited, a consequence not only of the small number of research projects in this field but also of the scarcity of human remains dated specifically to the fifth millennium cal BC.

Data is available for five Mesolithic sites (Poza l'Egua, Colomba, Los Canes, Paré de Nogales, J3) and three dated to the fifth-fourth millennia (Los Canes SU 7, Lumentxa and el Cotero de la Mina; the human bone from Cotero de la Mina used for the isotope analysis was not dated directly and its chronological attribution is inferred from its association with other human remains that were dated directly: Arias 2005, 2012) (Fig. 6).

The results reflect a certain variability in the diet of the Mesolithic groups in the region, which has been associated with the geographic location of the sites and interpreted as an indicator of territoriality among the last hunter-gatherer groups (Arias 2005). The human remains from the sites of Poza l'Egua, Colomba and J3 reflected the importance of marine

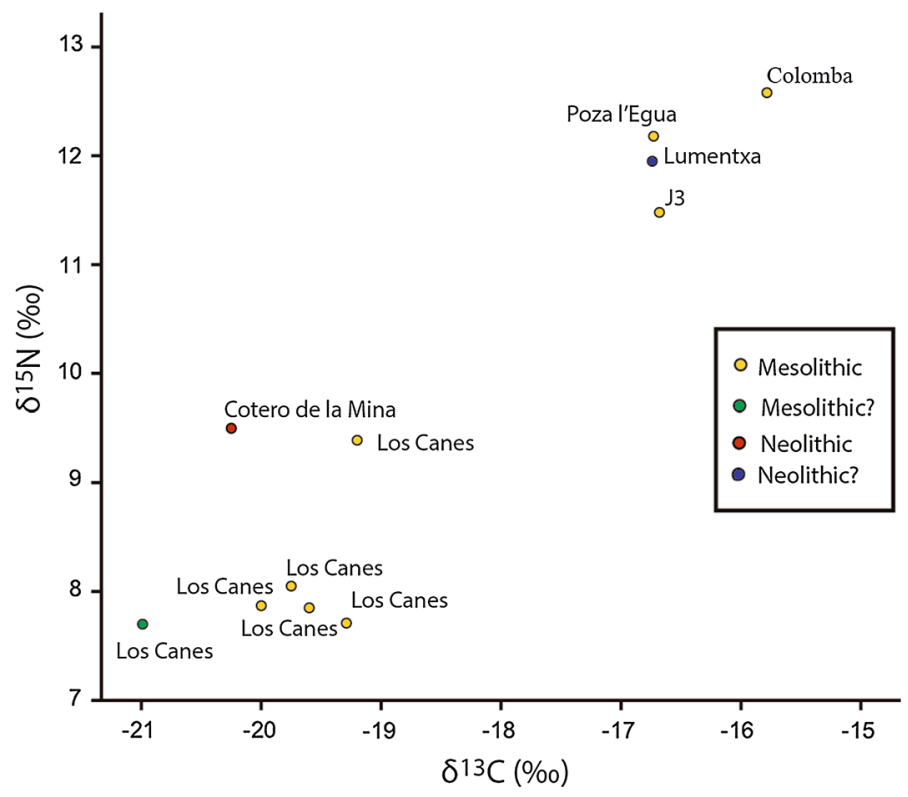

Fig. 6 Plot of values ${ }^{13} \mathrm{C}$ and ${ }^{15} \mathrm{~N}$ available for the Mesolithic and Neolithic in the Cantabrian region (modified from Arias 2005) 
resources in the diet of the Mesolithic communities, in accordance with the large quantities of marine molluscs found at these sites. However, the results from the site of Los Canes reflect a mainly terrestrial diet. This has been interpreted as evidence for the territoriality of the inland hunter-gatherer groups, which depended on terrestrial resources much more than groups living in coastal areas (Arias 2005).

Little data is available about the impact of the introduction of the farming economy in the region. The evidence for the fifth millennium cal BC is limited to a human bone dated directly from Level IV at Lumentxa (Arias 2012), although its stratigraphic context is not clear. The isotope analysis reflected a predominance of marine protein, interpreted as certain continuity in the use of coastal resources in the early Neolithic.

Finally, if the attribution of the human bone from Cotero de la Mina to the fourth millennium is accepted, then the main contribution of calories to the diet would come from terrestrial resources, reflecting a lesser use of marine resources in the diet of Neolithic populations (Arias 2005). Despite this, the archaeological evidence reveals a panorama in which marine resources continued to play a relatively important role in the diet of those human groups, as shown by the isotope analyses at Lumentxa and the documentation of large malacological assemblages in deposits dated in the fifth (Los Gitanos and Kobaederra) and fourth millennia (Mazaculos, Los Gitanos and Santimamiñe). The information available about palaeodiets does not allow a definite interpretation of the impact of the farming economy, and at first sight it appears to reflect a complex situation.

\section{New Technologies for a New Economy?}

\section{Pottery}

Most of the pottery assemblages attributed to the fifth and fourth millennia cal BC come from non-funerary sites (El Mirón, Los Gitanos, Kobaederra, Arenaza, Torca l'Arroyu, La Calvera, Las Covas and L'Hortal), while in other cases, a dubious association with isolated human remains has been cited (Los Canes, Barcenilla, Arenillas, Arenaza Level IC1, Lumentxa Level IV, Santimamiñe and Marizulo Level 1). In the same way, the few ceramic assemblages found in megalithic structures (La Xorenga) were mostly found in the mass of the tumulus and therefore unrelated stratigraphically to the funerary event.

In recent years, studies of Neolithic pottery in the region have been able to determine general aspects of the procurement and preparation of raw materials, the manufacturing process, and the forms and decoration of the end products. However, the functionality of the vessels is still largely unknown.

Studies show that raw materials available in the immediate surroundings of the sites were used (Cubas et al. 2014a, b; Cubas et al. 2012; Vega 2012). The clay fabric was either unmodified or prepared by adding some kind of temper, usually calcite, although other minerals and rocks have been identified. While mineral inclusions are more common, the use of artificial temper, such as grog, has also been observed (Cubas 2013). Despite the scarcity of diachronic information, certain changes can be seen in raw material procurement patterns and in the preparation of the clay fabric, as noted at Los Gitanos (Cubas et al. $2014 \mathrm{~b}$ ) and this may have been connected with a change in the function of the cave site.

The technological processes in the manufacture of the vessels are not easily identified. However, the slab-building technique and surface treatment of the vessels (smoothing, scraping, burnishing) have been documented from the time of the earliest pottery in the region (Cubas 2013). In general, little is known about the forms. The oldest assemblages 
(Monte Areo VI, Los Canes SU 7, Los Gitanos sub-Levels A4 and A3, Arenillas Level 0, El Mirón Levels 10, 303 and 303.3, Kobaederra Levels IV and III, and Arenaza Level IC2) are characterised by a lack of evidence about the forms because of the absence of reconstructible vessels or profiles. The characteristics of the sherds suggest that the receptacles were open, with a continuous profile and flat base. However, in some cases, as at Kobaederra, some vessels appear to have had a closed form, with rims turned inwards, while others were very open with everted rims and suspension systems. At El Mirón, one vessel, Vessel 16 was reconstructed: the lip was flat, the rim and body straight and the base was probably convex (Vega 2012).

This scarcity of information about the forms continues for the fourth millennium, although greater diversity has been observed, including globular forms and even necked vessels (Marizulo) and flat bases (Torca l'Arroyu, La Calvera and Marizulo). Elements for suspension are rare, apart from a possible handle in Level TA-3a at Torca l'Arroyu (Jordá et al. 2008), and a lug fragment at Los Gitanos (sub-Level A2). La Xorenga is the only megalithic structure that has yielded a reasonably abundant ceramic assemblage. The sherds hint at more-or-less closed receptacles, whose rims are turned inwards, and flat bases. In the late fourth millennium cal BC, increased diversity is seen, with open vessels, inferred from straight and/or everted rims, and closed forms whose rims turn inwards. In the same way, the form of the bases appears to vary, although this supposition is based on the identification of a single sherd of a pointed base (Cubas 2013). In other cases, for example Level 8 at El Mirón, no basal sherds have been found. The transition to the third millennium is possibly characterised by the appearance of vessels with a compound or carinated profile (El Toral III, Los Avellanos and Los Cavios) (Cubas and Vega in press).

Decorative elements are also scarce in fifth and fourth millennium pottery assemblages in northern Spain. These consist mainly of plain sherds, with decorated fragments completely absent from some sites (Los Gitanos sub-Levels A4 and A3, Kobaederra Level III, Monte Areo VI and La Xorenga). The decoration that has been documented is impressed, incised and plastic, in varying proportions depending on the levels and sites (see for example Kobaederra, Level III, Fig. 7). However, some shared characteristics are the location of the decorations on the outer surfaces and the representation of isolated geometric motifs. The decorative techniques are: incision (Los Canes, Mazaculos Level A2, Los Gitanos sub-Level A2, Torca l'Arroyu Level TA-3a Marizulo Level 1); plastic decoration alone (Los Gitanos sub-Level A2, El Mirón Level 8, Marizulo Level 1); plastic decoration together with impressed motifs (Los Gitanos sub-level A2, Level IV at Kobaederra, El Toral III and Los Avellanos); and impressed decoration made with various stamps (Level IV at Kobaederra, Levels IC2-IC1 at Arenaza, and Marizulo Level 1). Six sherds with 'boquique' decoration were also documented at the latter site (Alday 2003), although a recent reappraisal of the assemblage was unable to identify these sherds among the other fragments.

It can be seen that the pottery recorded in northern Spain in the fifth and fourth millennia cal $\mathrm{BC}$ is characterised by extreme fragmentation and heterogeneity, impeding the identification of forms or decorative patterns. The absence of morpho-stylistic traits limits opportunities for typological studies and the proposal of relative chronologies. The characteristics of the sherds and the sites where they are found are indicators of a domestic use that was apparently maintained over these two millennia. The scarceness of pottery assemblages at funerary sites in this period appears to suggest that they lacked any funerary or symbolic significance, but this seems to change in the late fourth millennium, when a certain relationship between the first incised pottery and funerary deposits is intuited. However, the uncertainties regarding these archaeological sites mean that this is only a hypothesis. 

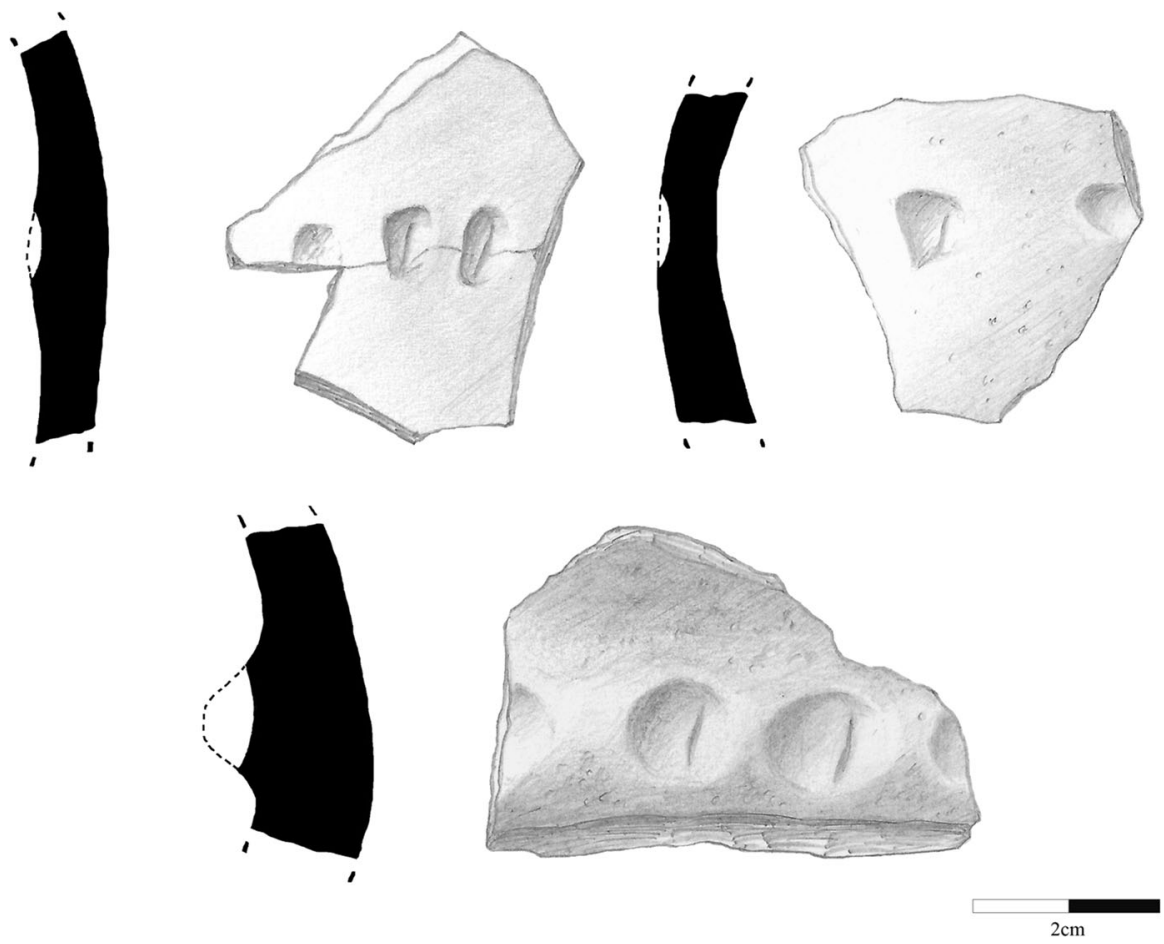

Fig. 7 Decorative techniques documented in the site of Kobaederra (Level IV)

\section{Lithic Industry}

The lithic industry from published Neolithic levels in northern Spain is unrepresentative and highly variable from the technological and typological points of view. Practically the sole distinctive trait shared by the sites is the presence of lunates and triangles with simple or Helwan retouching. These have been found in significant but generally small numbers. Retouched objects usually appear in proportions of under $10 \%$, and notches, denticulates, sidescrapers and blanks with retouched edges are the most common, together with endscrapers, splintered pieces and, to a lesser extent, borers (Iriarte et al. 2005; Mujika and Edeso 2011; Muñoz et al. 2013; Ontañón-Peredo et al. 2013; Straus and González Morales 2012; Zapata et al. 1997). Backed tools are common but variable and at most sites the production of small bladelets in situ has been attested.

The variety in the assemblages and the dearth of technological studies of these Neolithic collections makes it difficult to make comparisons with the Mesolithic collections, with which they share some technical characteristics, such as the similar proportions of blade and non-blade products. With the exceptions of Kobaederra (Zapata et al. 1997) (Fig. 8) and Herriko Barra (Iriarte et al. 2005), in situ production at all the sites appears to be limited to obtaining small blanks and making some of the most distinctive tools, such as geometrics, with the presence of micro-burins. Thus, at El Mirón, Arenillas and Los Gitanos, the small percentage of cores, remains with cortex, and maintenance products suggests that the main phases in the reduction sequence took place in areas outside the sites 


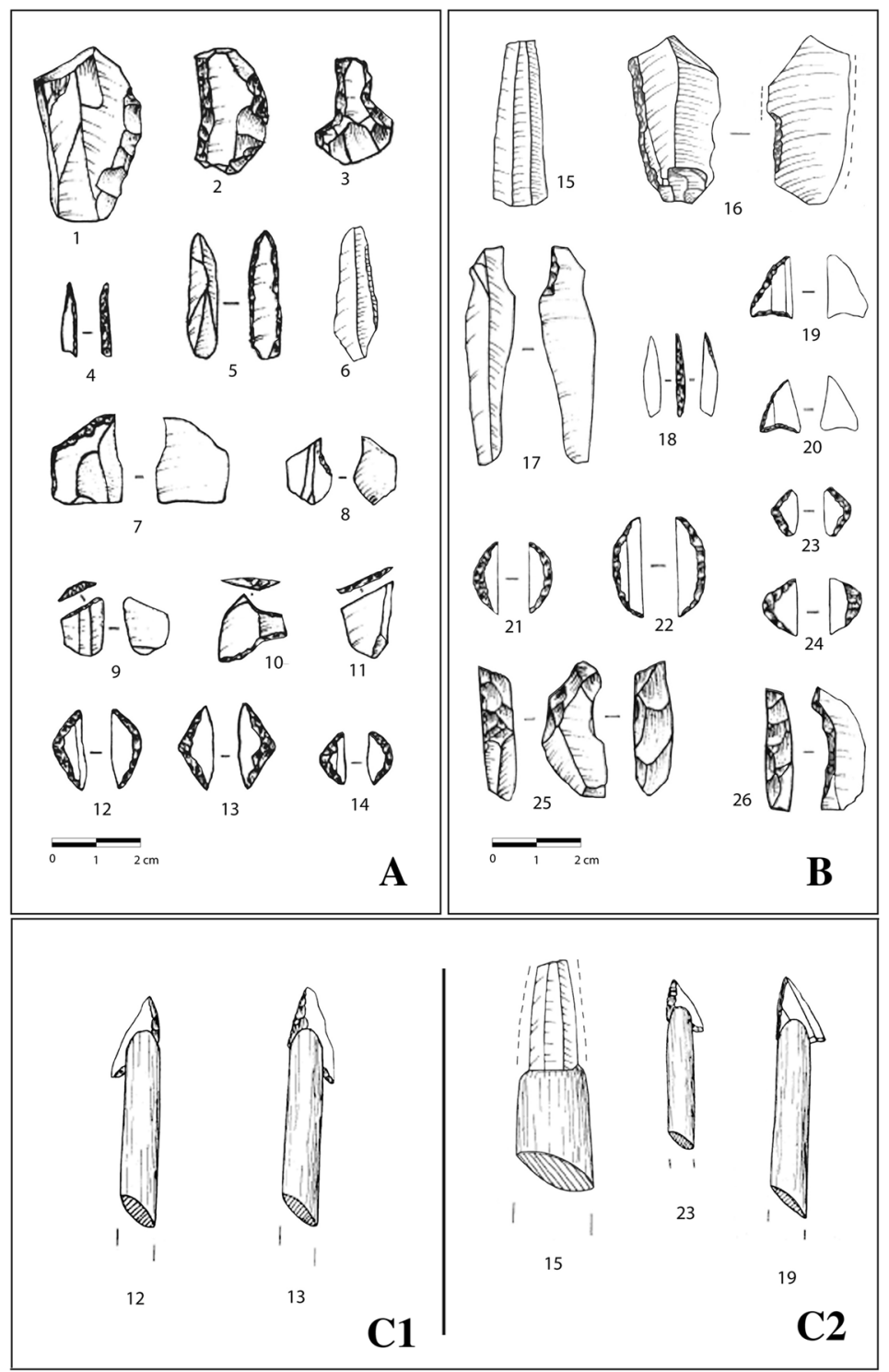

Fig. 8 Lithic industries from Kobaederra (Kortezubi, Biscay): a Level III; b Level IV; c results of functional analysis (adapted from Zapata et al. 1997 [a: 1-5, 7-14; b: 17-26] and Ibáñez 2001 [a: 6; b: 15-16; c1 and c2])

or in areas pending excavation (Muñoz et al. 2013; Ontañón-Peredo et al. 2013; Straus and González Morales 2012).

The available evidence indicates that the reduction methods and objects obtained were similar to those in the immediately preceding period, with blades and bladelets obtained from prismatic and pyramidal cores, and flakes from centripetal or globular cores (Iriarte et al. 2005). Descriptions of forms of percussion are limited to the use of a hard hammerstone and a possible example of removing blades by pressure at Kobaederra (Zapata et al. 1997). 
The use of raw materials of similar kinds to those used in previous periods also implies a continuum in the management of the resources known in the local and immediate surroundings, or in the means of obtaining resources, such as exchange networks. References to the use of flint varieties different from those used previously are vague and only seem to indicate a greater tendency to use the best quality varieties for making geometrics (Straus and González Morales 2012).

Most of the retouched tools lack any distinctive traits in their design or production and therefore it is in the group of geometrics, despite their highly varied level of representativeness, where a substantial difference is seen compared with the Mesolithic. This is marked by the appearance of circle segments and, to a lesser extent, triangles, made by simple or flat double-bevelled retouching. It is paradoxical that it is precisely microlithic armatures, presumably used for hunting, that are the only diagnostic elements in the lithic repertoire of the new farming way of life. The functional study of the assemblage from Kobaederra showed that the geometrics were indeed used as projectile armatures, and rejected other possible uses, such as harvesting (which have also not been identified on the rest of the toolkit). In contrast, it has been shown that other more common or undifferentiated tools were used in new productive techniques, like making pottery receptacles (Ibáñez 2001).

With the exception of Herriko Barra, interpreted as a seasonal settlement specialising in hunting (Iriarte et al. 2005), the other sites appear to correspond to dwellings where everyday tasks, including hunting, were carried out (Straus and González Morales 2012). However (and as stated above), in many cases it appears that the initial phases in the reduction sequence were performed away from the sites, but the lack of alternative sites does not allow this to be confirmed.

This poor definition of the lithic assemblages continues until the appearance of megalithic structures in the last third of the fifth millennium cal $\mathrm{BC}$, which in contrast is difficult to discriminate from later periods. As a consequence of the use of grave goods and a larger number of open-air habitation sites, it is now possible to find ground stone tools, adornments and implements such as blades obtained by pressure knapping in varieties of flint from distant sources, and sickle elements. These denote a significant change in the material culture of these Neolithic groups. Finds of axes and other ground stone tools are common across the whole region but can only be attributed for certain to Neolithic sites from the late fifth millennium onwards, both at open-air habitation sites (Jordá et al. 2008) and in dolmens (Mujika and Edeso 2011).

In the fourth millennium cal BC, even axes introduced from the Alps have been recorded in the region (Dima, Cangas) (Pétrequin et al. 2012). At this time, imported objects, imitations and local production of new items like axes are found together with traditional elements such as geometrics. Even Asturian picks continue to appear in a few cases, in connection with funerary structures (La Capilluca II and Las Mesas) (Marqués 2011), reflecting an association in the grave goods with other elements that are indirect evidence of the farming economy.

\section{Funerary Practices}

\section{Funerary Behaviour of the Last Hunter-Gatherers}

Research in recent years has led to an increase in the number of Mesolithic funerary sites known in the region. This is reflected in the density of sites-especially in the sixth 
millennium cal BC-in comparison with the density in the Upper Palaeolithic, which is in accordance with the situation in the rest of the Iberian peninsula. The northern coast is, after the centre and south of Portugal, the region with the largest number of burial sites (Arias 2012). However, unlike in Portugal and the Mediterranean coast (for example, the site of El Collado: Gibaja et al. 2015), most sites in the north contain a single individual.

Seven sites were undoubtedly used for burials in the Mesolithic: Tito Bustillo (Arias et al. 2009a, b); Los Canes (Arias 2002); La Paré de Nogales (Arias 2012); El Molino de Gasparín (Carballo 1926); El Truchiro (Armendariz et al. in press); Linatzeta (Tapia et al. 2008); and J3 (Iriarte et al. 2010). Two more sites are located very near the region: La Braña-Arintero, $14 \mathrm{~km}$ to the south of the watershed between the northern coast and the Douro river basin (Vidal and Prada 2010); and Aizpea, in the foothills of the Pyrenees (Barandiarán and Cava 2001). Human remains have also been found at the Asturian sites of Colomba (Arias et al. 2007a) and El Toral III (Noval 2013): part of the legs of a single individual in the former, and a skull, jaw fragment and pelvis fragment in the latter, but without anatomical connections or evidence of graves in which the bodies might have been placed. The interpretation is therefore difficult, especially in the case of El Toral III, as only preliminary information is available. The record at Colomba has been interpreted as part of the burial site dismantled by post-depositional processes, and this may also be the case at El Toral III.

The isolated human remains found in other Asturian shell-middens, like Mazaculos, Balmori (Garralda 1981), Cuartamentero (Garralda 1982), La Poza l'Egua (Arias et al. 2007b), Arangas (Arias et al. 2013) and El Mazo (Gutiérrez-Zugasti and González-Morales 2013) raise more doubts. It has been proposed that they may be the remains of burials that have been badly disturbed, but they may also be the consequence of different funerary practices (Arias 2012).

The known burial sites are all located in caves and rock-shelters. This is not surprising as hardly any open-air occupations are known, as discussed above. At the sites of La Braña-Arintero and Tito Bustillo, the funerary activity took place in interior parts of a cave that was not used as a dwelling. In the latter, the funerary evidence was also located in a remote part of the cave where, similarly, no Mesolithic occupation has been found. Cueva de los Canes is another case, as in this period the cave was only used for burials.

However, at most sites, the burials were carried out in places where Mesolithic occupations have been identified. The inhumation of bodies in shell-middens or deposits rich in shells is particularly interesting. This practice was documented in early stages of research (El Molino de Gasparín) and has been verified since then, with varying degrees of certainty, in more recent excavations at J3, El Truchiro, El Toral III and Colomba.

Different types of funerary sites have been documented: (1) burials in well-defined graves, at Los Canes, El Truchiro and J3; (2) sites defined as sepulchral, but in which no graves have been identified. This would be the case of the baby in a primary position in Linatzeta and remains not preserving anatomical connections at El Toral III and Colomba; (3) deposits of bodies on the floor of rock-shelters and caves. At Aizpea the body was covered afterwards by boulders of different sizes. At La Braña-Arintero and Tito Bustillo no kind of covering was documented.

As stated above, in most cases the sites contain a single individual. The exceptions are La Braña-Arintero, with two individuals in relatively proximate areas, and Los Canes, which is undoubtedly the most complex case. Three burials were found in this cave, as well as the remains of older pits that might have been dug for the same purpose. The burials were individual, although remains of more than one person have been found in the graves. Grave II was re-used, as the remains of an individual who had been buried previously were 
found, together with a practically complete skeleton. A large part of the skeleton of a child was found in the upper part of the fill in Grave III. The dates obtained for this infantile individual and associated artefacts suggest that the inhumation of the child was disturbed when the grave was reopened to bury an adult male.

The age and sex patterns indicate that funerary treatment was applied to both sexes. However, differences are seen in the age of death. They include advanced ages (Los Canes), adults (La Braña-Arintero, Aizpea and J3), juveniles (El Truchiro and Los Canes) and also children, one of whom was less than six months old (Linatzeta).

The bodies were laid in supine decubitus position and, above all, in lateral decubitus. The flexed position of the legs is therefore very common, but some individuals were placed in very forced bent postures ( $\mathrm{J} 3$ and Aizpea). In fact, in some cases it has been proposed that the bodies were tied up or wrapped in skins when they were buried or deposited (La Braña-Arintero and J3). At El Truchiro, the layer of tree bark found underneath the skeleton suggests that the body had been placed on a piece of wood or something similar.

It is common for the bodies to be accompanied by objects interpreted as votive offerings but at some sites no evidence has been found (Grave III at Los Caves, Linatzeta). The most outstanding example is Grave II at Los Canes, with a wide range of grave goods, not comparable with other funerary sites of this date. Personal adornments like shells or red deer canines have been found with several individuals (Individual 2 at La Braña-Arintero; Graves I and II at Los Canes and El Truchiro). Other types of object, like the pierced staff or the long bone awl found with the young individual in Grave II at Los Canes, are unusual. Lithic tools or the raw material for making them are common and include Asturian picks at El Molino de Gasparín, according to Carballo's interpretation, and flint cores at El Truchiro. Red colouring matter has been documented at Tito Bustillo and La Braña-Arintero. Also of interest is the possibility of food offerings: meat in Grave I at Los Canes, and perhaps continental snails (Cepaea nemoralis) in the same grave and at La Paré de Nogales.

\section{The Megalithic Phenomenon: The Change in Funerary Practices}

Several decades were spent debating whether the megalithic phenomenon in northern Spain was the earliest evidence of human groups with a food-producing economy. The introduction of this funerary rite is now regarded as the last step in a complex neolithisation process which began in the first half of the fifth millennium, although evidence of contacts between other Neolithic groups in the Iberian peninsula and local Mesolithic groups has been found, dated to the last centuries of the sixth millennium (Arias 2007). Nonetheless, megalithism marks the great conquest of inland parts of the regions. Structures of this kind can be found from practically sea level to over $1800 \mathrm{~m}$ altitude; from the coastline to the general watershed in the Cantabrian mountains. Over 1300 sites are known today, but their distribution is far from homogeneous, in connection with the tradition of research into the phenomenon in the region. In the west (the administrative region of Asturias), over 750 sites are catalogued; in the east (the Basque provinces of Biscay and Guipúzcoa), about 400 are known; while in the centre (Cantabria), the total does not reach 200 (Arias et al. 2006).

If the constructions are compared with the classic types, the most notable characteristic is the absence of passage tombs, structures clearly differentiating a burial chamber from the system of access from outside. Although this model was widely adopted in the neighbouring inland basins of the Ebro and the Douro and in Galicia, no monument of this 
kind has been found from the eastern end of the Basque Country to the River Navia in the west of Asturias (Teira 1994).

The megalithic structures built with orthostats are usually described as possessing a polygonal or rectangular floor plan of little over $2 \mathrm{~m}^{2}$ in surface area, with the orthostats placed vertically if the floor plan is polygonal, and horizontally if it is rectangular. These inner spaces are surrounded by tumuli averaging about $12 \mathrm{~m}$ in diameter, some of them reaching nearly $30 \mathrm{~m}$, while in contrast a large group of barrows are little over $6 \mathrm{~m}$ in diameter. An internal structure can sometimes be identified, although in many cases it is a simple imbrication of flat stones arranged to buttress the outward force of the stones forming the chamber. Small circles of stones are sometimes found surrounding the outer edge, or groups of loose stones on the surface of piles of earth. These were therefore monuments where it was necessary to move some of the stones to introduce a new inhumation, unless this was added through the interstices between the irregular orthostats. While this is the general rule, some monuments were larger, such as the Cotero de la Mina in Cantabria, whose chamber may have measured $5 \mathrm{~m}$ on its longest side (Armendariz and Teira 2008) (Fig. 9), or the dolmen of Santa Cruz in Asturias, some of whose orthostats are decorated and stood over $2 \mathrm{~m}$ high, and which was surrounded by an oblong tumulus over $37 \mathrm{~m}$ in its longest dimension (del Sella and Vega del Sella 1919). In the necropolis of Monte Areo in Cabo de Peñas (Asturias), the term 'dolmen with doorway' describes a chamber, Structure XV, which consisted of five orthostats placed upright and whose entrance was defined by two smaller stones (de Blas 1999). In contrast, the tumuli of other monuments surround 'unorthodox' areas, such as very small chambers marked by small stones, wooden structures, pavements or simple holes (de Blas 2006).

The grave goods are few in number but diverse in form and size, in contrast to the situation on the other side of the mountains to the south of the region. It is usual to find geometric, triangular or trapezoidal flint armatures made with the microburin technique

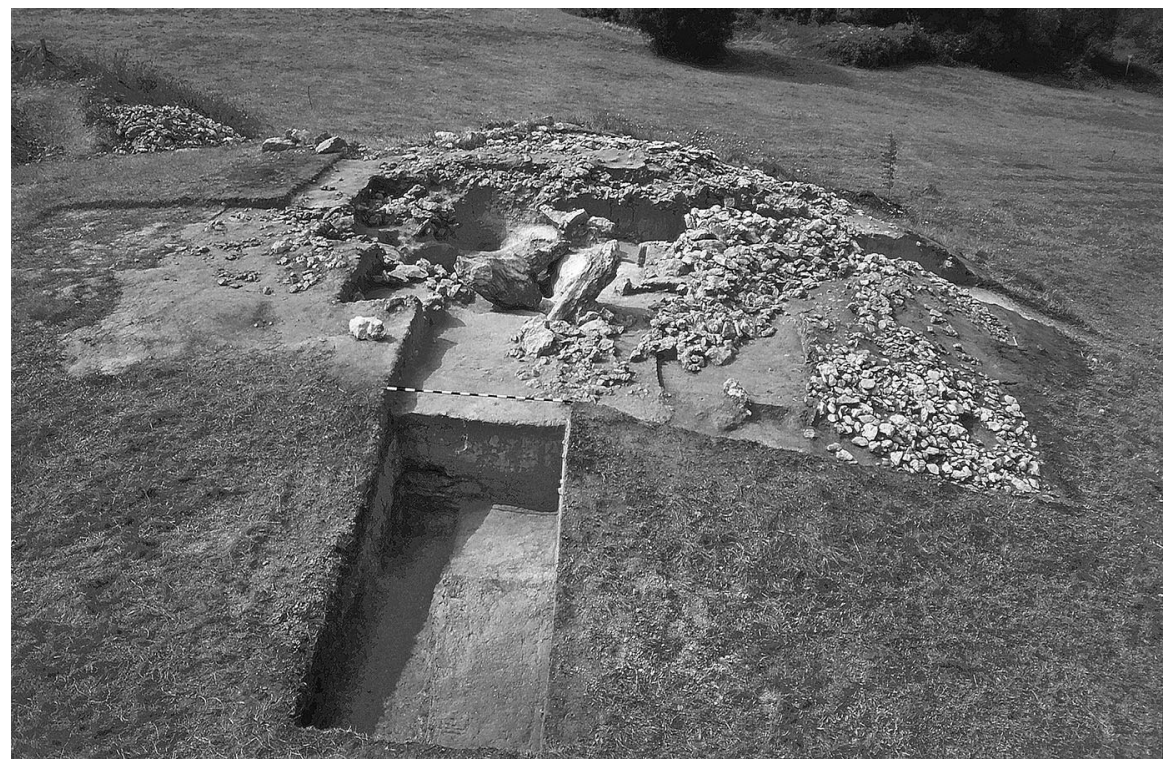

Fig. 9 General view of the dolmen Cotero de la Mina (Cantabria, Spain) 
and normally with double-bevelled retouching. Simple unretouched blades and bifacially retouched points with tangs or incipient appendices may also be found. However, most remarkable is the excellent quality of the flint used for many of these artefacts (Arias 2012). Ground stone axes or singular objects like prismatic rock crystals or fossils are also often found. Some prestige items may equally be cited, such as the pierced axe at Santa Cruz (del Sella and Vega del Sella 1919) and the gold ring at Mata'l Casare (de Blas 1994), clearly of a more recent period.

The establishment of the megalithic complex to the north of the Cantabrian mountains is comparable, in terms of radiocarbon dates, with the time span for the same type of monuments in the rest of northern Iberia. According to the dates for the building of these structures, and bearing in mind the methodological issues involved (Mujika 2007), it appears that this was not a gradual process but rather a phenomenon that was introduced rapidly, with a concentration of probabilities around 4100-3900 cal BC. However, they continued in use until the Early Bronze Age (Arias et al. 2006). Some older determinations (in the middle of the fifth millennium) have recently provoked an interesting debate on the way in which the rite was adopted (de Blas 2006). Although only a small number of structures are known, most of them enclose very unconventional spaces. They may be wooden structures, tiny spaces partially surrounded by small stones or simply holes. A suggestive hypothesis claims that these unorthodox structures acted as a point of reference when the standard dolmen was introduced. Then, when the more orthodox monuments were built, the old ones were sealed by covering them to give them the same appearance as the new structures (de Blas 2006). To date, the examples on which this hypothesis is based are limited to Asturias and it would be interesting to test the idea at further sites in the centre and east of the region.

\section{Not Only Megaliths ... Evidence of Continuity?}

Compared with the relatively abundant documentation for cave burials in the Mesolithic, evidence corresponding to the fifth and fourth millennia cal BC, in certain Neolithic contexts, is extremely scarce and incomplete.

In the first half of the fifth millennium, when the transition to the Neolithic occurred in the region, three cases are known, but their cultural attribution is dubious, precisely because they are situated in that transition period.

Cueva de los Canes (Cabrales, Asturias) contained an unusual concentration of burials, with several individual burials in pits dated to the seventh and sixth millennia cal BC. However, two radiocarbon determinations, one for a human bone $(5980 \pm 70 \mathrm{BP}$, TO$11219)$ and the other for charcoal encrusted in a potsherd (5865 $\pm 70 \mathrm{BP}, \mathrm{AA}-5788)$ suggest that the cave was still being used for burials in the early fifth millennium cal BC. However, as no evidence of a productive economy dated to the same time has been found in the cave, this burial should be associated with a late Mesolithic population rather than to the Neolithic (Arias 2012). Similarly, in Cueva de Lumentxa (Lekeitio, Biscay) a sample from an individual buried in a level attributed to the Neolithic during the first excavations at the site yielded a date in the second quarter of the fifth millennium cal BC $(6122 \pm 38$ BP, OxA-18236). This individual's diet, rich in marine proteins, also suggests a Mesolithic way of life rather than a Neolithic economy (Arias 2005). Finally, during the survey of the floor in the 'Burial Chamber' in the Cueva-Sima del Portillo del Arenal (Piélagos, Cantabria), remains of at least 16 individuals corresponding to different periods were found. They were accompanied by artefacts also belonging to very different periods, from late prehistory to the Early Middle Ages, so they cannot be related directly with them. One 
human bone provided a fairly imprecise date (5743 $\pm 111 \mathrm{BP}, \mathrm{AA}-20043)$, which would correspond to the early or middle fifth millennium cal BC (Muñoz and Morlote 2000), and other human bone was dated to the fourth millennium cal BC (Gutiérrez Cuenca and Hierro 2010).

The burial at Marizulo (Urnieta, Guipúzcoa), for a long time the only certain Neolithic burial known in the region and still the most complete and best documented, is dated at the end of the fifth millennium or the start of the fourth. This young adult male (about 25 years of age) was placed in a flexed position on an east-west line, inside a structure made of three large limestone boulders and open towards the east (the direction in which the body was facing). It was located at the base of Level I, which contains a collective burial with Chalcolithic and Bronze Age remains. The individual was apparently found with the bones of a dog (without the skull) and a lamb, but no other definite grave goods (Laborde et al. 1967). Two dates obtained more recently (Alday and Mujika 1999) for this burial, one directly for a human rib $(5315 \pm 100$, Ua-4818) and the other from the lamb that apparently accompanied the deceased (5235 \pm 75 , Ua-10375) agree with the original determination (5285 $\pm 65, \mathrm{GrN}-5992)$ (Altuna 1972).

The inhumations recently discovered in Cueva de Linatzeta (Deba, Guipúzcoa), a site still being excavated, are also probably dated to the late fifth millennium cal BP. In a small side passage, a series of dispersed human remains were found together with pottery fragments which appear to have been washed out of the main passage (where a Mesolithic burial was documented) by running water. Until the archaeological excavation progresses further, it will not be possible to know whether or not these remains belong to a collective burial with several individuals. However, the radiocarbon dates (still unpublished) situate them in the chronology mentioned above (Tapia et al. 2008).

The latest excavations in Cueva de Ekain (Deba, Guipúzcoa) (Altuna 2009) exhumed remains of what is apparently a Neolithic burial, but more recent than those in Cueva de Linatzeta. The mandible of an infantile individual was found in two fragments, along with some teeth that probably belong to the same anatomical piece. Sherds from several receptacles, one with lugs and the other decorated by fingernail impressions, were also found. These remains were dispersed practically from the modern cave floor and through three underlying levels belonging to the late Mesolithic, Azilian and Magdalenian, as if a pit had been dug and altered these layers. They may be what remains of a burial now completely dismantled, or part of an inhumation that may still be found in a proximate and unexcavated part of the deposit. The jaw was dated to the early fourth millennium cal BC $(4960 \pm 60$ BP, Ua-36855).

A series of human remains, possibly accompanied by undecorated sherds and a necklace made with shells of Trivia, found in the 'Main Chamber' in Cueva de El Calero II (Piélagos, Cantabria) must correspond to the mid fourth millennium. In this case, only one of the sherds presumably associated with the human remains has been dated by TL (5482 \pm 422, MAD-668) (Muñoz and Morlote 2000). Finally in the nearby Cueva-Sima del Portillo del Arenal, other remains, not associated with grave goods, were dated to the late fourth or early third millennium $(4443 \pm 104$, AA-20044), in the Late NeolithicChalcolithic transition.

In sum, as stated above, the available evidence for funerary practices in caves in northern Spain in the Neolithic is extremely poor. With the possible exception of Linatzeta, continuity from the Mesolithic can be appreciated in the ritual, which is characterised by individual burials. This is especially noteworthy in the fourth millennium cal BC, when the megalithic culture was firmly established in the region. It indicates a duality of funerary traditions whose significance is still completely unknown. 


\section{Discussion: Influences on the Neolithic in Northern Spain}

In the last three decades, the amount of information about the Neolithic in the region has increased enormously. This has enabled certain issues to be resolved but, above all, it has allowed hypotheses to be proposed and tested.

The available archaeological evidence does not permit an analysis of population patterns. However, with the current information a differential distribution of the settlements can be observed. Mesolithic sites are clearly most abundant in the western part of the region, particularly in the case of the Asturian shell-middens. However, hardly any sites are attributed to the first half of the fifth millennium, and those few that have been so attributed are 'anomalous' and difficult to interpret. In this region, the earliest evidence of agriculture in the form of cereal pollen (with the consequent doubts, see Behre 2007) comes from the Monte Areo peat bog (López-Merino et al. 2010) and Herriko Barra (Iriarte et al. 2005) in the Basque Country; while in the form of plant macro-remains, the earliest evidence appears in the fifth millennium, at the sites of El Mirón, Kobaederra, Pico Ramos and Lumentxa, all in the centre-east of the region. Domestic livestock is not documented in Asturias until the late fifth-early fourth millennia, at sites such as Torca l'Arroyu, Mazaculos II and Arangas, whereas in the rest of the region it clearly existed in the first half of the fifth millennium (e.g. at Los Gitanos, El Mirón, Arenaza and Kobaederra). This situation changes radically in the fourth millennium cal $\mathrm{BC}$, when the expansion of megalithic structures throughout the whole region signified the introduction of a new funerary ritual. The first open-air settlements (Las Corvas, L'Hortal and La Calvera) possibly appeared at the same time (their chronology is based on radiocarbon dates obtained from wood charcoal of unidentified species and might thus be artificially older: Fano et al. 2015).

These data might point to the focus of influence in the introduction of domestic species in the region. The archaeological sites in the eastern sector, where the earliest evidence of domesticates is known, are characterised by a certain change in subsistence and the arrival of new technologies such as pottery. The same 'unity' cannot be identified in the western sector, where the sites attributed to the fifth millennium may be considered 'anomalous' because they display certain aspects, such as pottery, without their being associated with evidence of exploitation of domesticated species. By the time domesticates arrived in the Cantabrian region, both the immediate east and south possessed plant domesticates as well (Peña-Chocarro et al. 2005a; Peña-Chocarro 2007). In addition to the possible Mediterranean introduction of the Neolithic crop assemblage to the Iberian peninsula along the Ebro valley (Arias 2007), the Western Pyrenees have been suggested as a possible route of introduction, though this still needs to be tested (Zapata 2002, Zapata and Peña-Chocarro 2005; Zapata et al. 2007).

Current evidence suggests the improbability of the introduction of plant domesticates to the Cantabrian region by populations travelling by sea from the Mediterranean along the Portuguese coast, creating 'Neolithic enclaves' (Zilhão 2003), which could account for the spread of domesticates in faraway coastal sites after a very short lapse of time. The evidence is very scarce for particular similarities between the Cantabrian region and other early Neolithic Iberian contexts from which the crops might have arrived; southern France and the northern Meseta are possible candidates (Zapata et al. 2007) for the origin of domesticates. To this can be added the poorly-defined forms of certain highly representative aspects of material culture, like pottery, which do not display a high correlation with the types in the Ebro valley, apart from the use of impressed techniques, poorly recorded 
(Arenaza) or the use of some kind of inclusions that are widely documented in the earliest Neolithic phases. Diachronic comparison with other regions in the vicinity, like the Ebro valley and the Western Pyrenees, indicates different rates in the transmission of pottery technology (Cubas 2013). These first receptacles do not reflect the typical characteristics of pottery assemblages in the western Mediterranean in the early Neolithic, as impressed decoration is practically unknown and the morphological and decorative aspects of the pottery are poorly defined.

Other elements and aspects of the economic, social and symbolic sphere suggest a certain continuity between the last hunter-gatherer groups and the first farming societies. In the economic sphere, this period was characterised by the importance of hunting. In this framework, livestock farming would have been introduced, although it is only represented in significant percentages at sites like El Mirón and Arenaza. Similarly, wild plants continued to be gathered, and early evidence of agriculture is very scant in the region. Levels of shell middens at sites dated after the start of the fifth millennium cal BC, like Mazaculos, Santimamiñe and Los Gitanos, also indicate continuity of the exploitation of marine resources. Underscoring this continuity are the isotope values of the human remains from Lumentxa, dated to the first half of the fifth millennium (Arias 2012).

However, continuity is perceptible not only in subsistence but also in other spheres. Although genetic studies have not been performed on all the evidence at the main sites in the region, the genetic analysis of Neolithic populations at the sites of Los Cascajos and Paternanbidea in the Ebro valley concluded that there was hardly any female genetic contribution from the populations where the Neolithic first developed (Hervella et al. 2012), which is thought to contradict a model of population replacement (Hervella et al. 2012). This absence of replacement would therefore indicate that the native population persisted and participated in the neolithisation process.

The technological sphere also displays some interesting aspects. Although pottery technology is mainly associated with sites characterised by a farming economy, some evidence of pottery has been found at sites where such an association is not so obvious (Cubas 2013). The presence of some tools, like Asturian picks, at megalithic sites also supports this idea of continuity and even the combination of traits typical of huntergatherer groups and farming communities. In the same way, lithic assemblages at the time reflect a greater emphasis on hunting rather than agriculture.

All this evidence appears to be indicating an 'availability phase' (Zvelebil and RowleyConwy 1986) during the initial stage of the introduction of a farming economy in the region. This raises the question of how the economic sphere was transformed once agriculture and husbandry had been adopted. The evidence of hunting and gathering activities and the high proportion of malacological remains in the known archaeological deposits, even during the fourth millennium cal BC, seem to advocate a process of gradual change, although new archaeological realities, like megalithic structures and pottery technology, begin to appear.

Acknowledgments Miriam Cubas is working within the framework of the European Commission-funded Marie Sklodowska Curie research project First ceramics of Atlantic Europe: Manufacture and function (CerAM -IF 653354-). This paper is a contribution to the research project 'Coastal societies in a changing world: A diachronic and comparative approach to the prehistory of SW Europe from the late Palaeolithic to the Neolithic' (CoChange) (HAR2014-51830-P), granted by the Plan Estatal de Investigación Científica y Técnica y de Innovación 2013-2016; Programa Estatal de Fomento de la Investigación Científica y Técnica de Excelencia; Subprograma Estatatal de Generación de Conocimiento of the Spanish Ministry of Economy and Competitiveness. We thank the anonymous reviewers for their careful reading of our manuscript and their many insightful comments and suggestions. 
Open Access This article is distributed under the terms of the Creative Commons Attribution 4.0 International License (http://creativecommons.org/licenses/by/4.0/), which permits unrestricted use, distribution, and reproduction in any medium, provided you give appropriate credit to the original author(s) and the source, provide a link to the Creative Commons license, and indicate if changes were made.

\section{References}

Alday, A. (2003). Cerámica neolítica en la región vasco-riojana: Base documental y cronológica. Trabajos de Prehistoria, 60(1), 19-50.

Alday, A., \& Mujika, J. A. (1999). Nuevos datos de cronología absoluta concerniente al Holoceno Medio en el área vasca. In El Mundo indígena (XXIV Congreso Nacional de Arqueología) (pp. 95-106). Murcia: Instituto de Patrimonio Histórico.

Altuna, J. (1972). Fauna de mamíferos de los yacimientos prehistóricos de Guipúzcoa. Munibe, 3(4), 1-464.

Altuna, J. (1980). Historia de la domesticación animal, en el País Vasco, desde sus orígenes hasta la romanización. Munibe, 32, 9-163.

Altuna, J. (1994). El perro en los yacimientos arqueológicos del norte de la Península Ibérica. In J. A. Lasheras (Ed.), Homenaje al Dr. Joaquín González Echegaray, Monografías 17 (pp. 159-162). Madrid: Museo y Centro de Investigación Altamira.

Altuna, J. (2009). Cueva de Ekain. Arkeoikuska, 2008, 358-365.

Altuna, J., \& Mariezkurrena, K. (1985). Bases de subsistencia de los pobladores de Erralla: Macromamíferos. Munibe (Antropologia-Arkeologia) Cazadores magdalenienses en Erralla (Cestona, País Vasco), 37, 87-117.

Altuna, J., \& Mariezkurrena, K. (2001). La cabaña ganadera del yacimiento de La Renke (Álava, País Vasco). Munibe (Antropologia-Arkeologia), 53, 75-86.

Altuna, J., \& Mariezkurrena, K. (2009). Tipos de cabañas ganaderas durante el Neolítico en el País Vasco y zonas próximas. Archaeofauna, 18, 137-157.

Altuna, J., \& Mariezkurrena, K. (2012). Macromammalian remains from the Holocene levels of El Mirón cave. In L. G. Straus \& M. R. González-Morales (Eds.), El Mirón cave, Cantabrian Spain: The site and its Holocene archaeological record (pp. 288-318). Albuquerque: University of New Mexico Press.

Álvarez-Fernández, E. (2006). Los objetos de adorno-colgantes del Paleolítico superior y Mesolítico en la Cornisa Cantábrica y en el Valle del Ebro: Una visión europea. Salamanca: Vítor.

Álvarez-Fernández, E. (2013a). Upper Pleistocene-Early Holocene transition at La Garma A cave (Omoño, Cantabria, Spain): Preliminary report on the marine molluscs. In G. N. Bailey, K. Hardy, \& A. Camara (Eds.), Shell energy: Mollusc shells as coastal resources (pp. 167-181). Oxford: Oxbow Books.

Álvarez-Fernández, E. (2013b). Retour à Marizulo (Urnieta, Guipúzcoa, Espagne): Etude préliminaire des ressources marines. In M.-Y. Daire, C. Dupont, A. Baudry, C. Billard, J. M. Large, L. Lespez, E. Normand, \& C. Scarre (Eds.), Anciens peuplements littoraux et relations Homme/Milieu sur les côtes de l'Europe atlantique, BAR International Series 2570 (pp. 403-409). Oxford: Archaeopress.

Álvarez-Fernández, E. (2015). Continuity of human-marine fauna interaction during the Holocene in Cantabrian Spain. Quaternary International, 364, 188-195.

Álvarez-Fernández, E., \& Altuna, J. (2013). La cueva de Marizulo (Urnieta, Gipuzkoa), 50 años después: Revisión de los restos arqueozoológicos de los niveles mesolíticos. Kobie, 32, 131-152.

Álvarez-Fernández, E., Altuna, J., Barrera-Melado, I., Cubas, M., Fernández-Gómez, M. J., Fernández, R., et al. (2014a). Évolution de l'exploitation des ressources animales dans la région cantabrique entre 4500 et 2000 cal BC: La grotte de Los Gitanos (Cantabrie, Espagne). Comptes Rendus Palevol, 13, 307-316.

Álvarez-Fernández, E., Aparicio, M. T., Armendáriz, Á., Arias, P., \& Ontañón-Peredo, R. (2013). Étude archéomalacologique du gisement mésolithique de El Truchiro Omoño, Ribamontán al Monte, Cantabria. Anthropozoologica, 48(1), 153-170.

Álvarez-Fernández, E., Chauvin, A., Cubas, M., Arias, P., \& Ontañón-Peredo, R. (2011). Mollusc shell sizes in archaeological contexts in northern Spain (13200 to $2600 \mathrm{cal} \mathrm{BC}$ ): New data from La Garma A and Los Gitanos (Cantabria). Archaeometry, 53(5), 963-985.

Álvarez-Fernández, E., Iriarte, M. J., Arrizabalaga, Á., Barrera-Mellado, I., Carriol, R.-P., FernándezGómez, M. J., et al. (2014b). Entre lapas: Primera valoración de los restos de origen marino del yacimiento holoceno de J3 (Hondarribia, País Vasco). Munibe (Antropologia-Arkeologia), 65, 67-78.

Álvarez-Fernández, E., Ontañón-Peredo, R., \& Molares-Vila, J. (2010). Archaeological data on the exploitation of the goose barnacle Pollicipes pollicipes (Gmelin, 1790) in Europe. Journal of Archaeological Science, 37, 402-408. 
Antolín, F., \& Buxó, R. (2012). Chasing the traces of diffusion of agriculture during the early Neolithic in the Western Mediterranean Coast. In M. Borrell, F. Borrell, J. Bosch, X. Clop, \& M. Molist (Eds.), Redes en el Neolítico: Circulación e intercambio de materias, productos e ideas en el Mediterráneo occidental (VII-III milenio aC), Rubricatum 5 (pp. 95-102). Gavà: Museu de Gavà.

Antolín, F., Jacomet, S., \& Buxó, R. (2015). The hard knock life: Archaeobotanical data on farming practices during the Neolithic (5400-2300 cal BC) in the NE of the Iberian Peninsula. Journal of Archaeological Science, 61, 90-104.

Aparicio, M. T. (2001). Malacofauna terrestre del yacimiento de Cubío Redondo (Matienzo, Cantabria). Munibe (Antropologia-Arkeologia), 53, 61-66.

Apellániz, J. M., \& Altuna, J. (1975). Excavaciones en la cueva de Arenaza I (San Pedro de Galdames, Vizcaya): Primera campaña, 1972. Neolítico y mesolítico final. Noticiario Arqueológico Hispánico. Prehistoria, 4, 121-154.

Arias, P. (1990). El fenómeno megalítico en la Asturias Oriental. Gallaecia, 12, 91-110.

Arias, P. (1991). De cazadores a campesinos: La transición al neolítico en la región cantábrica. Santander: Universidad de Cantabria/Asamblea regional de Cantabria.

Arias, P. (1997). ¿Nacimiento o consolidación? El papel del fenómeno megalítico en los procesos de neolitización de la región Cantábrica. In A. Rodríguez Casal (Ed.), O Neolítico Atlántico e as orixes do Megalitismo (pp. 371-389). Santiago de Compostela: Universidad de Santiago de Compostela.

Arias, P. (1999). Esquisse chronologique de la préhistoire post-paléolithique de la région cantabrique (Espagne). In J. Evin, C. Oberlin, J. P. Daugas \& J. F. Salles (Eds.), 14C et Archéologie (3ème Congrès International), Groupe des Méthodes Pluridisciplinaires Contribuant à l'Archéologie. Mémoires, 26 (pp. 259-263). Rennes: Société Préhistorique Française.

Arias, P. (2002). La cueva de Los Canes (Asturias): Los últimos cazadores de la Península Ibérica ante la muerte. Santander: Unpublished.

Arias, P. (2005). Determinaciones de isótopos estables en restos humanos de la Región Cantábrica. Aportación al estudio de la dieta de las poblaciones del Mesolítico y del Neolítico. Munibe (Antropologia-Arkeologia)(Homenaje a Jesús Altuna), 57(3), 359-374.

Arias, P. (2007). Neighbors but diverse: Social change in north-west Iberia during the transition from the Mesolithic to the Neolithic (5500-4000 cal BC). In A. Whittle \& V. Cummings (Eds.), Going over: The Mesolithic-Neolithic transition in north-west Europe. Proceedings of the British Academy, 144 (pp. 53-72.). Oxford: Oxford University Press.

Arias, P. (2012). Después de Los Azules: Las prácticas funerarias en las sociedades mesolíticas de la región cantábrica. In J. R. Muñiz Álvarez (Ed.), Ad Orientem: Del final del Paleolítico en el norte de España a las primeras civilizaciones del Oriente Próximo (pp. 253-274). Oviedo: Universidad de Oviedo.

Arias, P., \& Altuna, J. (1999). Nuevas dataciones absolutas para el Neolítico de la cueva de Arenaza (Bizkaia). Munibe (Antropologia-Arkeologia), 51, 161-171.

Arias, P., Álvarez-Fernández, E., Cubas, M., Teira, L. C., Tapia, J., Cueto, M., et al. (2013). Intervención arqueológica en el sistema kárstico de Arangas (Cabrales): Campaña de 2007. Excavaciones arqueológicas en Asturias 2007-2012, Consejería de Cultura (pp. 121-133). Principado de Oviedo: Oviedo.

Arias, P., Armendáriz, Á., Balbín, R., Fano, M. Á., Fernández-Tresguerres Velasco, J. A., González Morales, M. R., et al. (2009a). Burials in the cave: New evidence on mortuary practices during the Mesolithic of Cantabrian Spain. In S. B. McCartan, R. Schulting, G. Warren, \& P. Woodman (Eds.), Mesolithic horizons (pp. 650-656). Oxford: Oxbow Books.

Arias, P., Armendariz, A., \& Teira, L. (2006). The megalithic complex in Cantabrian Spain. In A. Rodríguez Casal (Ed.) Le mégalithisme atlantique: The Atlantic megaliths. Acts of the XIVth UISPP Congress, BAR International Series 1521 (pp. 11-29). Oxford: Archaeopress.

Arias, P., Cubas, M., Fano, M. A., Álvarez, E., Araújo, A. C., Cueto, M., et al. (in press). Une nouvelle approche pour l'étude de l'habitat mésolithique dans le nord de la Péninsule Ibérique : Recherches dans le site au plein air d'El Alloru (Asturies, Espagne). Bulletin de la Société préhistorique française.

Arias, P., Cubas, M., Fano, M. A., Jordá, J. F., Salzmann, Ch., Teichner, F., \& Teira, L. C. (2015). Where are the 'Asturian' dwellings? An integrated survey programme on the Mesolithic of northern Spain. Antiquity, 89, 783-799.

Arias, P., \& Fano, M. Á. (2009). ¿Mesolítico geométrico o mesolítico con geométricos? El caso de la región cantábrica. In P. Utrilla \& L. Montes (Eds.), El Mesolítico geométrico en la Península Ibérica, Monografías arqueológicas 44 (pp. 69-91). Zaragoza: Universidad de Zaragoza.

Arias, P., Fano, M. Á., Armendáriz, Á., Álvarez-Fernández, E., Cueto, M., Fernández García, R., et al. (2007a). Programa de sondeos en concheros holocenos del Oriente de Asturias. In Excavaciones arqueológicas en Asturias 1999-2002 (pp. 107-116). Oviedo: Principado de Asturias. 
Arias, P., Fernández, P., Marcos, C., \& Rodríguez, I. (2009b). The elusive flint: Raw materials and lithic technology in the Mesolithic of eastern Asturias, Spain. In S. B. McCartan, R. Schulting, G. Warren, \& P. Woodman (Eds.), Mesolithic horizons (pp. 860-872). Oxford: Oxbow Books.

Arias, P., Fernández-Tresguerres Velasco, J. A., Álvarez-Fernández, E., Armendáriz, Á., Cueto, M., Fano, M. Á., et al. (2007b). Excavación arqueológica de urgencia en la cueva de La Poza l'Egua (Lledías, Llanes). In Excavaciones arqueológicas en Asturias 1999-2002 (pp. 227-240). Oviedo: Principado de Asturias.

Arias, P., \& Schulting, R. J. (2010). Análisis de isótopos estables sobre los restos humanos de La BrañaArintero. Aproximación a la dieta de los grupos mesolíticos de la cordillera cantábrica. In J. M. Vidal \& M. E. Prada (Eds.), Los hombres mesolíticos de la cueva de La Braña-Arintero (Valdelugueros, León) (pp. 130-137). León: Junta de Castilla y León (Estudios y catálogos 18).

Armendáriz, A. (1987). Problemas sobre el origen del megalitismo en el País Vasco. In El megalitismo en la Península Ibérica (pp. 143-148). Madrid: Subdirección General de Arqueología y Etnología.

Armendáriz, Á., Arias, P., \& Ontañón-Peredo, R. (in press). A grave in the lab: The late Mesolithic burial at El Truchiro cave (Cantabria, northern Spain). In P. Arias \& N. Cueto (Eds.), Meso 2010: Proceedings of the eighth international conference on the Mesolithic in Europe (Santander 13th-17th September, 2010). Oxford: Oxbow.

Armendariz, A., \& Teira, L. (2008). El Megalitismo en la Marina Occidental de Cantabria: Excavación arqueológica del dolmen El Cotero de la Mina (San Vicente de la Barquera). VI Campaña (2000). In Actuaciones arqueológicas en Cantabria. 2000-2003 (pp. 107-110). Santander: Consejería de Cultura, Turismo y Deporte del Gobierno de Cantabria.

Arribas, A., \& Molina, F. (1984). Estado actual de la investigación del Megalitismo en la península Ibérica. In Scripta Praehistorica, Francisco Jordá Oblata (pp. 63-112). Salamanca: Universidad de Salamanca.

Bailey, G. N., \& Craighead, A. S. (2003). Late Pleistocene and Holocene coastal paleoeconomies: A reconsideration of the molluscan evidence from Northern Spain. Geoarchaeology, 18(2), 175-204.

Balsera, V., Bernabeu Aubán, J., Costa-Caramé, M., Díaz-del-Río, P., García Sanjuán, L., \& Pardo, S. (2015). The radiocarbon chronology of southern Spain's late prehistory (5600-1000 cal BC): A comparative review. Oxford Journal of Archaeology, 34(2), 139-156.

Barandiarán, I., \& Cava, A. (2001). Cazadores-recolectores en el Pirineo Navarro: El sitio de Aizpea entre 8000 y 6000 antes de ahora, Anejos de Veleia. Series Maior 10. Vitoria: Universidad del País Vasco.

Bayliss, A., Ramsey, C. B., van der Plicht, J., \& Whittle, A. (2007). Bradshaw and Bayes: Towards a timetable for the Neolithic. Cambridge Archaeological Journal, 17(1), 1-28.

Behre, K. H. (2007). Evidence for Mesolithic agriculture in and around central Europe? Vegetation History and Archaeobotany, 16(2), 203-219.

Bohigas, R., \& Muñoz, E. (2002). Excavaciones arqueológicas de urgencia en el covacho de Arenillas (Islares, Castro Urdiales). 1992. In R. Ontañón Peredo (Ed.), Actuaciones arqueológicas en Cantabria 1987-1999 (pp. 45-47). Santander: Gobierno de Cantabria. Consejería de Cultura, Turismo y Deporte.

Carballo, J. (1926). El esqueleto humano más antiguo de España. Santander: Ed. del autor.

Castaños, P. (1997). Estudio arqueozoológico de la fauna de Peña Larga (Ciprán, Álava). Memoria de yacimientos alaveses, 4, 127-134.

Castaños, P. (2005). Estudio arqueozoológico de la fauna de Mendandia (Sáseta, Treviño). In A. Alday (Ed.), El campamento prehistórico de Mendandia: Ocupaciones mesolíticas y neolíticas entre el 8500 y el 6400 BP, Colección Barandiarán 9 (pp. 427-448). Vitoria: Diputación Foral de Álava.

Cava, A. (1988). Estado actual del conocimiento del neolítico en el País Vasco peninsular. Veleia, 5, 61-96.

Cava, A., Alday, A., \& Tarriño, A. (2007). La circulación de materias primas líticas en la transición Mesolítico/Neolítico antiguo en el País Vasco. Los abrigos de Mendandia, Kanpanoste y Aizpea. Kobie (Homenaje a Ignacio Barandiarán Maestu), 24-25(I), 581-610.

Clemente, I., Cuenca, D., Gutiérrez-Zugasti, I., González-Morales, M. R. (2010). The use of lithic tools for Mesolithic coastal hunter-gatherers from northern Spain: Experimental program for functional analysis on 'Asturian picks' from Mazaculos II (Asturias, Spain). In A. Arias \& M. Cueto (Eds.), The eighth international conference on the Mesolithic in Europe. Santander 13th-17th, 2010. Final programme and abstracts (pp. 218-219). Santander: Instituto Internacional de Investigaciones Prehistóricas de Cantabria.

Craighead, A. S. (1995). Marine mollusc as paleoenvironmental and paleoeconomic indicators in Cantabria Spain, Unpublished $\mathrm{PhD}$ dissertation, University of Cambridge.

Cubas, M. (2013). La aparición de la tecnología cerámica en la región cantábrica, BAR International Series 2566. Oxford: Archaeopress.

Cubas, M., de Pedro, I., \& Arias, P. (2014a). La aparición de la tecnología cerámica en Asturias: La aportación de la cueva de Los Canes (Arangas, Cabrales). Nailos: Estudios Interdisciplinares de Arqueología, 1, 23-48. 
Cubas, M., Doherty, C., García-Heras, M., de Pedro, I., Méndez, D., \& Ontañón-Peredo, R. (2014b). Pottery manufacturing during the Neolithic in the north of Spain: Raw material procurement and modification in the cave of Los Gitanos (Castro Urdiales, Spain). Archaeometry, 56(S1), 19-35.

Cubas, M., García-Heras, M., Méndez, D., de Pedro, I., Zapata, L., Ibáñez, J. J., \& González-Urquijo, J. E. (2012). La tecnología cerámica de los niveles IV y III en el yacimiento de Kobaederra (Cortézubi, Bizkaia): Aprovisionamiento y modificación de materias primas. Trabajos de Prehistoria, 69(1), 51-64.

Cubas, M., \& Vega, C. (in press). La cerámica en la región cantábrica entre el V y el IV milenio cal BC: Contextos de aparición y secuencias de manufactura. Sautuola.

Cuenca, D. (2011). Instrumentos de trabajo y elementos de adorno en conchas de molusco de la cueva de Santimamiñe (Kortezubi, Bizkaia). In J. C. López Quintana (Ed.), La cueva de Santimamiñe: Revisión y actualización (2004-2006), Kobie-Bizkaiko Arkeologi Indusketak-BAI 1 (pp. 155-170). Bilbao: Bizkaiko Foru Aldundia.

Cuenca, D. (2013). Utilización de instrumentos de concha para la realización de actividades productivas en las formaciones económico-sociales de cazadores-recolectores-pescadores y primeras sociedades tribales de la fachada atlántica europea, Serie Tesis doctorales 4. Santander: PubliCAN.

Cuenca, D., Clemente, I., \& Gutiérrez Zugasti, I. (2010). Utilización de instrumentos de concha durante el Mesolítico y Neolítico inicial en contextos litorales de la región cantábrica: Programa experimental para el análisis de huellas de uso en materiales malacológicos. Trabajos de Prehistoria, 67(1), 211-225.

Cuenca, D., Gutiérrez-Zugasti, I., \& Clemente-Conde, I. (2011). The use of molluscs as tools by coastal human groups: Contribution of ethnographical studies to research on Mesolithic and early Neolithic contexts in northern Spain. Journal of Anthropological Research, 67(1), 77-102.

Cunningham, P. (2005). Assumptive holes and how to fill them: A series of experiments investigating the pit storage potential of hazelnuts and acorns. EuroRea, 2, 55-66.

de Blas, M. A. (1983). La prehistoria reciente en Asturias, Estudios de Arqueología Asturiana (1st ed.). Oviedo: Fundación Pública de Cuevas y Yacimientos Prehistóricos de Asturias.

de Blas, M. A (1987). La ocupación megalítica en el borde costero cantábrico: El caso particular del sector asturiano. In El megalitismo en la Península Ibérica (pp. 127-141). Madrid: Ministerio de Cultura.

de Blas, M. A. (1994). El anillo áureo de tiras de la Mata'l Casare I y su localización megalítica. Madrider Mitteilungen, 35, 107-122.

de Blas, M. A. (1999). El Monte Areo, en Carreño (Asturias): Un territorio funerario de los milenios V a III a. de J.C. Carreño: Ayuntamiento de Carreño, Mancomunidad Cabo de Peñas,.

de Blas, M. A. (2006). La arquitectura como fin de un proceso: Una revisión de la naturaleza de los túmulos prehistóricos sin cámaras convencionales en Asturias. Zephyrus, 59, 233-255.

Deith, M., \& Shackleton, N. (1986). Seasonal exploitation of marine molluscs: Oxygen isotope analysis of shell from La Riera cave. In L. G. Straus \& G. A. Clark (Eds.), La Riera cave: Stone Age huntergatherer adaptations in northern Spain (pp. 299-313). Tempe: Arizona State University Press.

del Sella, V., \& Vega del Sella, C. D. (1919). El dolmen de la capilla de Santa Cruz (Asturias). Madrid: Museo Nacional de Ciencias Naturales.

Díez-Castillo, A. (1991). El megalitismo en los valles interiores del Occidente de Cantabria. In XX Congreso Nacional de Arqueología (pp. 191-197). Zaragoza: Secretaría General de los Congresos Nacionales de Arqueología.

Díez-Castillo, A. (1996). Utilización de los recursos en la marina y montañas cantábricas: Una prehistoria ecológica de los valles del Deva y Nansa. Illunzar, 3.

Díez-Castillo, A., Díaz, Y., \& Robles, G. (1995). La neolitización en las comarcas de Liébana y Polaciones (Cantabria): Implicaciones socio- económicas. In $1^{\circ}$ Congresso de Arqueologia Peninsular (pp. 55-71). Porto: Sociedade Portuguesa de Antropologia e Etnologia.

Elorza, M. (1993). ¿Pingüinos en Zarautz?: Sobre el hallazgo de la especie extinta Pinguinus impennis en el yacimiento de Herriko Barra. Aranzadiana, 114, 71-73.

Fano, M. A. (1998). El hábitat mesolítico en el Cantábrico Occidental, BAR International Series 732. Oxford: Archaeopress.

Fano, M. A. (2004). Un nuevo tiempo: El Mesolítico en la Región Cantábrica. In M. A. Fano (Ed.), Las Sociedades del Paleolítico en la Región Cantábrica, Kobie, Anejos 8 (pp. 337-402). Bilbao: Diputación Foral de Bizkaia.

Fano, M. A., Cubas, M., \& Wood, R. (2015). The first farmers in Cantabrian Spain: Contribution of numerical chronology to understand an historical process. Quaternary International, 364, 153-161.

Fano, M. A., Gutiérrez-Zugasti, I., Álvarez-Fernández, E., \& Fernández, R. (2013). Late Glacial and postglacial use of marine resources in the Bay of Biskay, North Spain. In G. N. Bailey, K. Hardy, \& A. Camara (Eds.), Shell energy: Mollusc shells as coastal resources (pp. 155-166). Oxford: Oxbow Books. 
Fernández-Mier, M., \& González-Álvarez, D. (2013). Más allá de la aldea: Estudio diacrónico del paisaje en el entorno de Vigaña (Belmonte de Miranda). Excavaciones arqueológicas en Asturias 2007-2012 (pp. 353-365). Oviedo: Consejería de Cultura, Principado de Asturias.

García-Escárzaga, A. (2014). El Mesolítico Asturiense en el Occidente de Cantabria: Revisión de la información disponible a través de una reflexión crítica. Kobie, 32, 113-130.

Garralda, M. D. (1981). Las mandíbulas de Balmori y Mazaculos II (Asturias): Estudio antropológico. Boletín del Instituto de Estudios Asturianos, 103, 595-603.

Garralda, M. D. (1982). El cráneo asturiense de Cuartamentero (Llanes, Asturias). Kobie, 12, 7-29.

Gibaja, J. F., Eulàlia Subirá, M., Terradas, X., Santos, F. J., Agulló, L., Gómez-Martínez, I., et al. (2015). The emergence of Mesolithic cemeteries in SW Europe: Insights from El Collado (Oliva, Valencia, Spain) radiocarbon record. PLOS ONE, 10(1), 1-18.

González-Morales, M. R. (1982). El Asturiense y otras culturas locales: La explotación de las áreas litorales de la región cantábrica en los tiempos epipaleolíticos, Monografías 7. Santander: Centro de Investigación y Museo de Altamira.

González-Morales, M. R. (1992). Mesolíticos y megalíticos: La evidencia arqueológica de los cambios en las formas productivas en el paso al megalitismo en la costa cantábrica. In A. Moure (Ed.), Elefantes, ciervos y ovicaprinos: Economía y aprovechamiento del medio en la Prehistoria de España y Portugal (pp. 185-202). Santander: Servicio de Publicaciones de la Universidad de Cantabria.

González-Morales, M. R. (1995a). La transición al Holoceno en la Región Cantábrica: el contraste con el modelo del mediterráneo español. In V. Villaverde Bonilla (Ed.), Los últimos cazadores: Transformaciones culturales y económicas durante el Tardiglaciar y el inicio del Holoceno en el ámbito mediterráneo (pp. 63-78). Alicante: Instituto de Cultura Juan Gil-Albert.

González-Morales, M. R. (1995b). Memoria de los trabajos de limpieza y toma de muestras en los yacimientos de las cuevas de Mazaculos y El Espinoso (La Franca, Ribadedeva) y La Llana (Andrín, Llanes) en 1993. Excavaciones arqueológicas en Asturias, 1991-1994 (pp. 65-78). Oviedo: Principado de Asturias.

González-Morales, M. R. (1996). La transición al neolítico en la costa cantábrica: La evidencia arqueológica. In I Congrès del Neolític a la Península Ibérica, Rubricatum I, vol. II (pp. 879-885). Gavà: Museu de Gavà.

González-Morales, M. R., Márquez Uría, M. C., Díaz, T. E., Ortea Rato, J. A., \& Volman, K. (1980). Informe preliminar de las excavaciones en el conchero asturiense de la cueva de Mazaculos II (La Franca, Asturias, campañas de 1976-78). Noticiario Arqueológico Hispánico (Prehistoria), 9, 37-62.

Gutiérrez Cuenca, E., \& Hierro, J. A. (2010) Nuevas evidencias sobre el uso de las cuevas de Cantabria durante la Tardoantigüedad y la Alta Edad Media: Primeros resultados del Proyecto Mauranus. Sautuola, 16-17, 263-280.

Gutiérrez-Zugasti, F. I. (2009a). La explotación de moluscos y otros recursos litorales en la región cantábrica durante el Pleistoceno Final y el Holoceno inicial. Santander: Ediciones de la Universidad de Cantabria.

Gutiérrez-Zugasti, F. I. (2009b). Explotación de recursos costeros durante el Neolítico en el área de la Reserva de Urdaibai: los moluscos de la cueva de Kobaederra (Kortezubi, Bizkaia). Munibe (Antropologia-Arkeologia), 60, 175-186.

Gutiérrez-Zugasti, F. I. (2011a). Coastal resource intensification across the Pleistocene-Holocene transition in Northern Spain: Evidence from shell size and age distribution of marine gastropods. Quaternary International, 244, 54-66.

Gutiérrez-Zugasti, F. I. (2011b). The use of echinoids and crustaceans as food during the PleistoceneHolocene transition in northern Spain: Methodological contribution and dietary assessment. Journal of Island and Coastal Archaeology, 6, 115-133.

Gutiérrez-Zugasti, F. I. (2011c). Los moluscos alimenticios de la cueva de Santimamiñe (Kortezubi, Bizkaia): Campañas de excavación 2004-2006. In J. C. López Quintana (Ed.), La cueva de Santimamiñe: revisión y actualización (2004-2006), Kobie-Bizkaiko Arkeologi Indusketak-BAI 1 (pp. 247-266). Bilbao: Bizkaiko Foru Aldundia.

Gutiérrez-Zugasti, F. I., \& González-Morales, M. R. (2013). Intervención arqueológica en la cueva de El Mazo (Andrín, Llanes) campañas de 2009, 2010 y 2012. In Excavaciones arqueológicas en Asturias 7 2007-2012 (pp. 159-167). Oviedo: Principado de Asturias.

Gutiérrez-Zugasti, I., González-Morales, M. R., Cuenca, D., Fuertes, N., García Moreno, A., Ortiz, J. E., et al. (2014). La ocupación de la costa durante el Mesolítico en el Oriente de Asturias: Primeros resultados de las excavaciones en la cueva de El Mazo (Andrín, Llanes). Archaeofauna, 23, 25-38.

Hervella, M., Izagirre, N., Alonso, S., Fregel, R., Alonso, S., Cabrera, V. M., \& de la Rúa, C. (2012). Ancient DNA from hunter-gatherer and farmer groups from northern Spain supports a random dispersion model for the Neolithic Expansion into Europe. PLOS ONE, 7(4), 1-10.

Holst, D. (2010). Hazelnut economy of early Holocene hunter-gatherers: A case study from Mesolithic Duvensee, northern Germany. Journal of Archaeological Science, 37(11), 2871-2880. 
Ibáñez, J. J. (2001). La función de los útiles retocados del yacimiento de Kobaederra (Oma, Vizcaya): Campañas de 1995, 96 y 97. Isturiz, 11, 225-244.

Iriarte, M. J., Arrizabalaga, A., Etxeberria, F., Herrasti, L., \& Álvarez-Fernández, E. (2010). Shell midden people in northern Iberia: New data from the Mesolithic rock shelter of J3 (Basque Country, Spain). Zephyrus, 65, 117-127.

Iriarte, M. J., Mujika, J. A., \& Tarriño, A. (2005). Herriko Barra (Zarautz-Gipuzcoa): Caractérisation industrielle et économique des premiers groupes de producteurs sur le littoral basque. In Unité et diversité des processus de néolithisation sur la façade atlantique de l'Europe, Mémoire 36 (pp. 127-136). Paris: Société Préhistorique Française.

Isern, N., Fort, J., Carvalho, A. F., Gibaja, J. F., \& Ibáñez, J. J. (2013). The Neolithic transition in the Iberian peninsula: Data analysis and modeling. Journal of Archaeological Method and Theory, 21(2), 447-460.

Jones, G. E. M. (2000). Evaluating the importance of cultivation and collecting in Neolithic Britain. In A. Fairbairn (Ed.), Plants in Neolithic Britain and beyond (pp. 79-84). Oxford: Oxbow Books.

Jordá, J., Estrada, R., Mestres, J. S., Yravedra, J., \& Marín, C. (2008). Un asentamiento neolítico de superficie en el interior de una cueva: Torca l'Arroyu (Llanera, Asturias, España). In M. Hernández, J. A. Soler, \& J. A. López (Eds.), IV Congreso del Neolítico Peninsular (pp. 208-215). Alicante: Museo Arqueológico de Alicante.

Laborde, M., Barandiarán, J. M. D., Atauri, T., \& Altuna, J. (1967). Excavaciones en Marizulo (Urnieta) (Campañas de 1965 y 1967). Munibe, 3(4), 261-269.

Laborde, M., de Barandiarán, J. M., Atauri, T., \& Altuna, J. (1965). Excavaciones en Marizulo (Urnieta). Munibe, 17, 103-107.

Laborde, M., de Barandiarán, J. M., Atauri, T., \& Altuna, J. (1966). Excavaciones en Marizulo (Campaña de 1964). Munibe, 1(4), 33-36.

López-Dóriga, I. (2015). An experimental approach to the taphonomic study of charred hazelnut remains in archaeological deposits. Anthropological and Archaeological Sciences, 7(1), 39-45.

López-Dóriga, I., \& Simões, T. (2015). Los cultivos del Neolítico Antiguo de Sintra: Lapiás das Lameiras y São Pedro de Canaferrim: resultados preliminares. In V. Gonçalves, M. Diniz, \& A. C. Sousa (Eds.), Actas do $5^{\circ}$ Congresso do Neolitico Peninsular, Estudos y Memórias 8 (pp. 96-105). Lisbon: Centro de Arqueología da Universidad de Lisboa.

López-Merino, L., Martínez, A., \& López, J. A. (2010). Early agriculture and palaeoenvironmental history in the north of the Iberian peninsula: A multi-proxy analysis of the Monte Areo mire (Asturias, Spain). Journal of Archaeological Science, 37(8), 1978-1988.

López Quintana, J. C. (2005). Organización del territorio durante la transición al Neolítico en el Cantábrico oriental: los ejemplos de Urdaibai y Gorbeia. In P. Arias Cabal, R. Ontañón-Peredo, \& C. GarcíaMoncó (Eds.), III Congreso del Neolítico en la Península Ibérica (pp. 435-444). Santander: Universidad de Cantabria (Monografía del Instituto Internacional de Investigaciones Prehistóricas de Cantabria I).

López-Sáez, J. A., López-Merino, L., \& Pérez, S. (2010). Neolitización, Megalitismo y antropización del paisaje en Galicia entre el VII y el IV milenio cal BC. In J. Fernández Eraso \& J. A. Mujika (Eds.), Actas del Congreso Internacional sobre Megalitismo y otras manifestaciones funerarias contemporáneas en su contexto social, económico y cultural, Suplemento no 32 (pp. 488-496). Donostia-San Sebastián: Sociedad de Ciencias Aranzadi.

Marchand, G. (2014). Préhistoire atlantique: Fonctionnement et évolution des sociétés du Paléolithique au Néolithique. Arles: Errance (Collection Hespérides).

Mariezkurrena, K., \& Altuna, J. (1995). Fauna de mamíferos del yacimiento costero de Herriko Barra (Zarautz, País Vasco). Munibe (Antropologia-Arkeologia), 47, 23-32.

Marín, A. B., \& González-Morales, M. R. (2009). Comportamiento económico de los últimos cazadoresrecolectores y primeras evidencias de domesticación en el occidente de Asturias: La cueva de Mazaculos II. Trabajos de Prehistoria, 66(1), 47-74.

Marinval, P. (1995). Recol-lecció i agricultura de l'epipaleolític al neolític antic: Anàlisi carpològica de la Balma de la Margineda. In J. Guilaine \& M. Martzluff (Eds.), Las excavacions a la Balma de la Margineda (pp. 65-77). Andorra: Edicions del Govern d'Andorra.

Marqués, A. C. (2011). Objetos de prestigio en ajuares funerarios mesolíticos y neolíticos de la región cantábrica (6000-3000 cal BC). Universidad de Cantabria, Unpublished.

Martins, H., Oms, F. X., Pereira, L., Pike, A. W. G., Rowsell, K., \& Zilhão, J. (2015). Radiocarbon dating the beginning of the Neolithic in Iberia: New results, new problems. Journal of Mediterranean Archaeology, 28(1), 105-131.

Mujika, J. A. (2007). Cronología y secuencias de uso funerario en el megalitismo del Pirineo Occidental. Illunzar, 7, 13-38. 
Mujika, J. A., \& Edeso, J. M. (2011). Los primeros agricultores y ganaderos en Gipuzkoa del Neolítico a la Edad del Hierro. San Sebastián: Diputación Foral de Gipuzkoa.

Muñoz, E., \& Morlote, J. M. (2000). Documentación arqueológica de la cueva del Calero II y la Sima del Portillo del Arenal, en Piélagos. In R. Ontañón-Peredo (Ed.), Actuaciones arqueológicas en Cantabria 1984-1999 (pp. 263-266). Santander: Consejería de Cultura, Turismo y Deporte.

Muñoz, E., Morlote, J. M., Santamaria, S., Castaños, P., Ruiz, B., Gil, M. J., \& Uzquiano, P. (2013). Sondeo arqueológico en el Abrigo de Barcenilla (T. M. de Piélagos, Cantabria). Kobie, 32, 79-112.

Noval, M. A. (2013). Excavación arqueológica en la cueva de El Toral III (Andrín, Llanes). In Excavaciones Arqueológicas en Asturias 2007-2012 (pp. 381-384). Oviedo: Consejería de Cultura, Principado de Asturias.

Ontañón-Peredo, R. (1995). El neolítico final y el calcolítico en el Cantábrico. Cuadernos de Sección. Prehistoria-Arqueología (Primeros agricultores y Ganaderos en el Cantábrico y valle del Ebro), 6, 83-104.

Ontañón-Peredo, R., Altuna, J., Álvarez-Fernández, E., Chauvin, A., Cubas, M., Fernández, R., et al. (2013). Contribution à l'étude de la néolithisation dans la région Cantabrique: La grotte de Los Gitanos (Cantabrie, Espagne). In M.-Y. Daire, C. Dupont, A. Baudry, C. Billard, J. M. Large, L. Lespez, E. Normand, \& C. Scarre (Eds.), Anciens peuplements littoraux et relations homme/milieu sur les côtes de l'Europe atlantique, BAR International Series 2570 (pp. 383-390). Oxford: Archaeopress.

Peña-Chocarro, L. (2007). Early agriculture in central and southern Spain. In S. Colledge \& J. Conolly (Eds.), The origins and spread of domestic plants in Southwest Asia and Europe (pp. 173-187). London: UCL Institute of Archaelogy/Left Coast Press.

Peña-Chocarro, L., \& Zapata, L. (2012). Las transformaciones económicas del Neolítico en la Península Ibérica: La agricultura. In M. Rojo, R. Garrido-Pena, \& I. García-Martínez de Lagrán (Eds.), El Neolítico en la Península Ibérica y su contexto europeo (pp. 95-106). Madrid: Cátedra.

Peña-Chocarro, L., Zapata, L., García, J., González-Morales, M. R., Sesma, J., \& Straus, L. G. (2005a). The spread of agriculture in northern Iberia: New archaeobotanical data from El Mirón cave (Cantabria) and the open-air site of Los Cascajos (Navarra). Vegetation History and Archaeobotany, 14, 268-278.

Peña-Chocarro, L., Zapata, L., Iriarte, M. J., González-Morales, M. R., \& Straus, L. G. (2005b). The oldest agriculture in northern Atlantic Spain: New evidence from El Mirón Cave (Ramales de la Victoria, Cantabria). Journal of Archaeological Science, 32(4), 579-587.

Pétrequin, P., Errera, M., Martin, A., Fábregas Valcarce, R., \& Vaquer, J. (2012). Les haches en jades alpins pendant les $V^{\mathrm{e}}$ et $\mathrm{IV}^{\mathrm{e}}$ millénaires: L'exemple de l'Espagne et Portugal dans une perspective européenne. Rubricatum, 5, 213-222.

Riddervold, A., \& Ropeid, A. (1988). Food conservation: Ethnological studies. London: Prospect Books.

Rojo, M. A., Garrido Pena, R., Martínez, García, de Lagrán, I., \& Tejedor Rodríguez, C. (2008). Los primeros agricultores y ganaderos del interior peninsular: Diez años de investigaciones arqueológicas en el Valle de Ambrona (Soria). Junta de Castilla y León: Caja Duero, Ayuntamiento de Miño de Medinaceli.

Rojo Guerra, M. A., Peña-Chocarro, L., Rojo Guillén, J. I., Tejedor Rodríguez, C., Martínez, García, de Lagrán, Í., et al. (2013). Pastores transhumantes del Neolítico Antiguo en un entorno de alta montaña: Secuencia crono-cultural de la Cova de Els Trocs (San Feliú de Veri, Huesca). Boletín del Seminario de Estudios de Arte y Arqueología, 79, 9-56.

Roselló, E., \& Morales, A. (2011). Evidencias de pesca en las ocupaciones de Santimamiñe. In J. C. LópezQuintana (Ed.), La cueva de Santimamiñe: Revisión y actualización (2004-2006), Kobie-Bizkaiko Arkeologi Indusketak-BAI 1(pp. 239-46). Bilbao: Bizkaiko Foru Aldundia.

Ruiz-Alonso, M., Guenaga, A., López-Quintana, J. C., \& Zapata, L. (2010). Antracología y yacimientos dolménicos: El caso de Mendigana (Areatza-Villaro, Bizkaia). In J. Fernández Eraso \& J. A. Mujika (Eds.), Actas del Congreso Internacional sobre Megalitismo y otras manifestaciones funerarias contemporáneas en su contexto social, económico y cultural, Suplemento no 32 (pp. 566-581). DonostiaSan Sebastián: Sociedad de Ciencias Aranzadi.

Ruiz-Alonso, M., \& Tapia, J. (in press). The study of plant macro-remains from Linatzeta (Lastur, Deba, Spain). In P. Arias \& M. Cueto (Eds.), Meso 2010: Proceedings of The Eighth International Conference on the Mesolithic in Europe (Santander 13th-17th September, 2010). Oxford: Oxbow.

Ruiz-Cobo, J. (1991). Implantación y desarrollo de las economías de producción en Cantabria. Unpublished $\mathrm{PhD}$, Universidad de Cantabria.

Scaife, R. G. (1992). Excavations at Mesolithic sites at Thatcham, Berkshire: Plant macrofossils. Proceedings of the Prehistoric Society, 58, 41-76.

Score, D., \& Mithen, S. (2000). Experimental roasting of hazelnuts. In S. Mithen (Ed.), Hunter-gatherer landscape archaeology: The southern Hebrides Mesolithic project 1988-1998 (pp. 507-512). Cambridge: McDonald Institute for Archaeological Research. 
Serna, M. R. (1997). Neolitización y megalitismo en la cornisa cantábrica: El yacimiento de Guriezo- Hayas. In II Congreso de Arqueología Peninsular (pp. 199-206). Zamora: Fundación Rei Afonso Henriques.

Stika, H. P. (2005). Early Neolithic agriculture in Ambrona, Provincia Soria, central Spain. Vegetation History and Archaeobotany, 14, 189-197.

Straus, L. G., \& González-Morales, M. R. (2012). El Mirón Cave, Cantabria Spain: The site and its Holocene archaeological record. Albuquerque: University of New Mexico Press.

Tapia, J., Álvarez-Fernández, E., Cubas, M., Cueto, M., Etxeberria, F., Gutiérrez-Zugasti, I., et al. (2008). La cueva de Linatzeta (Lastur, Deba, Gipuzkoa): Un nuevo contexto para el estudio del Mesolítico en Gipuzkoa. Munibe (Antropologia-Arkeologia), 59, 119-131.

Tarriño, A. (2006). El sílex en la cuenca vasco-cantábrica y el Pirineo navarro, Monografías Centro de Investigación y Museo de Altamira. Madrid: Ministerio de Cultura.

Teira, L. C. (1994). El megalitismo en Cantabria: Aproximación a una realidad olvidada. Santander: Servicio de Publicaciones de la Universidad de Cantabria.

Teira, L. C. (1995). Historiografía del Megalitismo en la Cornisa Cantábrica. In I. Actes (Ed.), Congres del Neolític a la Península Ibèrica, Rubricatum (vol. 2, pp. 481-485). Gavà: Museu de Gavà.

Uzquiano, P. (1995). L'évolution de la végétation à l'Holocène initial dans le nord de l'Espagne à partir de l'étude anthracologique de trois sites archéologiques. Quaternaire, 6(2), 77-83.

Vega, C. (2012). The ceramics of El Mirón cave: Production, morphology and discard. In L. G. Straus \& M. R. González-Morales (Eds.), El Mirón Cave, Cantabria Spain: The site and its Holocene archaeological record (pp. 372-425). Albuquerque: University of New Mexico.

Vidal, J., \& Prada, M. E. (2010). Los hombres mesolíticos de la cueva de La Braña-Arintero (Valdelugueros, León), Estudios y Catálogos 18. León: Junta de Castilla y León.

Vigne, J. D. (2005). L'humérus de chien magdalénien d'Erralla (Gipuzkoa, Espagne) et la domestication tardiglaciaire du loup en Europe. Munibe (Antropologia-Arkeologia) (Homenaje a Jesús Altuna), 57, 279-287.

Wood, R. (2015). From revolution to convention: The past, present and future of radiocarbon dating. Journal of Archaeological Science, 56, 61-73.

Zapata, L. (2000). La recolección de plantas silvestres en la subsistencia Mesolítica y Neolítica. Complutum, $11,157-169$.

Zapata, L. (2002). La explotación de los recursos vegetales y el origen de la agricultura en el País Vasco: Análisis arqueobotánico de macrorrestos vegetales, Kobie Anejo 4. Bilbao: Diputación Foral de Bizkaia.

Zapata, L. (2005). Agricultura prehistórica en el País Vasco. Munibe (Antropologia-Arkeologia) (Homenaje a Jesús Altuna), 57(1), 553-561.

Zapata, L., Ibañez, J. J., \& González-Urquijo, J. E. (1997). El yacimiento de la cueva de Kobaederra (Oma, Kortezubi, Bizkaia). Resultados preliminares de las campañas de excavación 1995-97. Munibe (Antropologia-Arkeologia), 49, 51-63.

Zapata, L., Milner, N., \& Roselló, E. (2007). Pico Ramos cave shell midden: the Mesolithic-Neolithic transition by the Bay of Biscay. In N. Milner, O. E. Craig, \& G. N. Bailey (Eds.), Shell middens in Atlantic Europe (pp. 150-157). Oxford: Oxbow Books.

Zapata, L., \& Peña-Chocarro, L. (2005). L’agriculture néolithique de la façade atlantique européenne. In G. Marchand \& A. Tresset (Eds.), Unité et diversité des processus de néolithisation sur la façade atlantique de l'Europe (6 $6^{e}-4^{e}$ millénaires avant J.-C), Mémoire 36 (pp. 189-199). Paris: Société Préhistorique Française.

Zapata, L., Peña-Chocarro, L., Pérez-Jordà, G., \& Stika, H.-P. (2004). Early Neolithic agriculture in the Iberian Peninsula. Journal of World Prehistory, 18, 283-325.

Zapata, L., Peña-Chocarro, L., Pérez-Jordá, G., \& Stika, H. P. (2005). Difusión de la agricultura en la Península Ibérica. In P. Arias, R. Ontañón-Peredo, \& C. García-Moncó (Eds.), III Congreso del Neolítico en la Península Ibérica (pp. 103-104). Santander: Instituto Internacional de Investigaciones Prehistóricas de Santander.

Zilhão, J. (2003). The Neolithic transition in Portugal and the role of demic diffsion in the spread of agriculture across West Mediterranean Europe. In A. J. Ammerman \& P. Biagi (Eds.), The widening harvest: The Neolithic transition in Europe: Looking back, looking forward (pp. 207-223). Boston: Archaeological Institute of America.

Zvelebil, M., \& Rowley-Conwy, P. (1986). Foragers and farmers in Atlantic Europe. In M. Zvelebil (Ed.), Hunters in transition: Mesolithic societies of temperate Eurasia and their transition to farming (pp. 67-93). Cambridge: Cambridge University Press. 